\title{
Lannea acida A. Rich. (Anacardiaceae) Ethanol Extract Exhibits Estrogenic Effects and Prevents Bone Loss in an Ovariectomized Rat Model of Osteoporosis
}

\author{
Mouchili Riepouo Oumarou, ${ }^{1}$ Stéphane Zingue, ${ }^{1,2}$ \\ Berlise Yengwa Bakam, ${ }^{2}$ Sylvin Benjamin Ateba, ${ }^{1}$ Simplice Harquin Foyet, ${ }^{3}$ \\ Fritz Teddy Tchaptchet Mbakop, ${ }^{2}$ and Dieudonné Njamen ${ }^{1}$ \\ ${ }^{1}$ Department of Animal Biology and Physiology, Faculty of Science, University of Yaounde 1, P.O. Box 812, Yaounde, Cameroon \\ ${ }^{2}$ Department of Life and Earth Sciences, Higher Teachers' Training College, University of Maroua, P.O. Box 55, Maroua, Cameroon \\ ${ }^{3}$ Department of Biological Sciences, Faculty of Sciences, University of Maroua, P.O. Box 814, Maroua, Cameroon
}

Correspondence should be addressed to Stéphane Zingue; stephanezingue@gmail.com

and Dieudonné Njamen; dnjamen@gmail.com

Received 6 July 2017; Accepted 25 October 2017; Published 27 November 2017

Academic Editor: Eman Al-Sayed

Copyright (C) 2017 Mouchili Riepouo Oumarou et al. This is an open access article distributed under the Creative Commons Attribution License, which permits unrestricted use, distribution, and reproduction in any medium, provided the original work is properly cited.

\begin{abstract}
Phytoestrogens have been shown to prevent postmenopausal osteoporosis. Lannea acida is a medicinal plant traditionally used in Cameroon to treat infertility, gynaecological complaints, and rheumatism. These uses prompted us to evaluate estrogenic activity of Lannea acida bark ethanolic extract and its antiosteoporotic potential in ovariectomized Wistar rats. In vitro, the E-screen assay was used to assess the ability of $L$. acida extract to induce MCF-7 cells proliferation. In vivo, a 3-day uterotrophic assay and a 12 -week oral treatment in ovariectomized adult rats were carried out to evaluate the ability of $L$. acida extract to prevent bone mass loss. $L$. acida extract induced MCF-7 cell proliferation. In vivo, it significantly increased the uterine wet weight, uterine and vaginal epithelial heights, and mammary glands differentiation. At $200 \mathrm{mg} / \mathrm{kg}$, a long-term treatment with the extract prevented body weight gain $(p<0.05)$ and loss of bone mass and/or density $(p<0.05)$ induced by ovariectomy. Also, a significant $(p<0.001)$ decrease of alkaline phosphatase activity was observed with $50 \mathrm{mg} / \mathrm{kg}$. L. acida extract improved bone microarchitecture and could restore normal bone mineralization by increasing the inorganic phosphorus and calcium level in bone. These findings provide evidence that Lannea acida is a potential alternative for the prevention of postmenopausal osteoporosis.
\end{abstract}

\section{Introduction}

Estrogen is steroidal hormone mainly produced by ovaries, which greatly fluctuates during women's lifespan and declines with menopause [1]. In addition to its role in primary organs like uterus, vagina, and mammary glands, it plays an important role in bone growth and homeostasis. Genetic, nutritional, and lifestyle factors as well as estrogen deficiency following the menopause are known to increase osteoclastic bone resorption rate and then risk of osteoporosis [2, 3]. Osteoporosis is a worldwide threat characterized by a bone mass loss linked to a low mineral content and microarchitectural deterioration of bone tissue leading to bone fragility and increased risk of fracture [4]. These fractures occur mainly in hip, spine, and wrist and are a major cause of morbidity and mortality in elderly populations $[3,5]$. According to the International Osteoporosis Foundation [6], the number of elderly people is increasing throughout the globe. Accordingly, the incidence of related fractures and costs for treatment will rise dramatically unless effective prophylactic measures are taken. It is estimated that the incidence of hip fracture will rise from 1.66 million in 1990 to 6.26 million by 2050 [7]. Osteoporosis and fragility fractures are believed to be uncommon in Africa. However, in a 2-year period study conducted in two urban hospitals in Cameroon, Zebaze and Seeman [8] reported that among all women patients aged 35 years and older diagnosed 
for fracture the hip and wrist fractures related to bone fragility were the most common pattern.

For decades, effective treatment such as antiresorptive bisphosphonates and hormone replacement therapy (HRT) has been used for managing postmenopausal osteoporosis [9, 10]. Unfortunately, the uses of bisphosphonates are often associated with gastrointestinal intolerance and osteonecrosis of the jaws [11]. Moreover, HRT is involved in adverse outcomes after long-term use such as increased risk of endometrial and breast cancers, stroke, and pulmonary thromboembolism $[12,13]$. Due to these reports women turned to alternatives. Efforts have been made for decades to find nonhormonal, effective and safer antiosteoporotic alternatives. In line with this interest in phytoestrogens rose significantly as they mimic estrogenic activity and might be promising.

In our ongoing research of novel phytoestrogens from plant, we sought a scientific rationale for the traditional use of Lannea acida (syn. Odina acida) (Anacardiaceae), commonly called "faruhi" in Fulani-Fulfulde (Nigeria), "faàrú" in Hausa, "Mipadi" in Giziga, or "Timbiya" in Moundang in Cameroun [14], and growth in Sub-Saharan Africa. Barks of L. acida are traditionally used in Nigeria as antiabortifacient, vermifuge and to treat anal haemorrhoids, diarrhoea, dysentery, malnutrition, and debility [15] and in Cameroon to treat dysmenorrhea, amenorrhea, and infertility, while the leaves treat rheumatism [16]. Information provided by the traditional healer in Moutourwa (Far North Region of Cameroon) revealed that the maceration of $L$. acida stem bark in local alcoholic drink (palm wine) is used to treat diarrhoea and gynaecological complaints. Ahmed et al. [17] showed that the methanolic extract of $L$. acida increased mobility, morphology, and sperm count as well as testosterone level in Wistar rats. Moreover, 4 flavonoids have been isolated from barks of L. acida [18], but to the best of our knowledge, no estrogenic activity of this plant has been investigated to date. Therefore, the present study aimed to evaluate in vitro and in vivo estrogenic activities of the ethanolic extract of stem bark of L. acida and to assess the antiosteoporotic potential of this extract in ovariectomized Wistar rats.

\section{Materials and Methods}

2.1. Chemicals. $17 \beta$-Estradiol valerate (Progynova ${ }^{\circledR} 2 \mathrm{mg}$ ) was purchased from DELPHARM (Lille, France). Penicillin (Xtapen ${ }^{\circledR}$ ) was provided by CSPC Zhongnuo Pharmaceutical (Shijiazhuang City, China). Diclofenac (Dicloecnu ${ }^{\circledR}$ ) was provided by ECNU Pharmaceutical (Yanzhou City, China). The cell culture medium was purchased from Cultilab (São Paulo, SP). Serum and antibiotics were purchased from GIBCO (Grand Island, NY). The $17 \beta$-estradiol benzoate [(estr1,3,5(10)-trien-3,16 $\alpha, 17 \beta$-triol); purity $\geq 98 \%$ ] was obtained from Sigma-Aldrich (Hamburg, Germany). The 2-[4-(2hydroxyethyl)piperazin-1-yl]ethane sulfonic acid (HEPES, purity $\geq 99.5 \%$ ) was purchased from Ludwig Biotecnologia Ltda (Alvorada, RS, Brazil). Trypan blue, quercetin, Alamar Blue, and Sulforhodamine-B were purchased from SigmaAldrich (St. Louis, MO, USA).

\subsection{Plant Material}

2.2.1. Collection and Authentication. The stem barks of Lannea acida A. Rich. (Anacardiaceae) were harvested in Moutourwa (Far North Region of Cameroon) on 6 July 2014 (pluvial season) around 11:30 a.m. The plant was localized at the geographical coordinates of $\mathrm{N}^{\circ} 12.681^{\prime}$ East and E0 $14^{\circ} 11.623^{\prime}$ altitude with a "ESTREX” Global Positioning System. This botanical sample was identified and authenticated by Mr. Victor Nana, botanist at the National Herbarium of Cameroon (HNC-IRA), by comparison to the specimen deposited under the voucher number 40942 HNC.

2.2.2. Extraction. The collected stem barks of $L$. acida were cleaned and air-dried at room temperature for 14 days. Then, $2000 \mathrm{~g}$ of the powder was macerated in $95 \%$ ethanol at room temperature ( $6 \mathrm{~L}$ of solvent $\times 3,48 \mathrm{~h}$ per extraction). The combined solutions were filtered using a Whatman filter paper number 4 and evaporated under reduced pressure $\left(337 \mathrm{mbar}\right.$ at $40^{\circ} \mathrm{C}$ ) using a rotary evaporator to afford $272 \mathrm{~g}$ of crude extract (a yield of $13.6 \%$ ). The extract was kept at $4-8^{\circ} \mathrm{C}$ and dissolved in distilled water prior to administration.

2.2.3. Preliminary Phytochemical Screening. Investigation on phytochemical composition of $L$. acida ethanol extract was performed according to the method described by Odebiyi and Sofowora [19]. Concentrations of some bioactive phytochemicals, such as total phenols, flavonoids, and alkaloids, were measured according to methods described by Singleton and Rossi [20], Zhishen et al. [21], and Fazel et al. [22], respectively.

\subsection{In Vitro Experiments}

2.3.1. Cell Line System. The human $\mathrm{ER}^{+}$breast adenocarcinoma MCF-7 cells were obtained from the Rio de Janeiro Cell Bank (Federal University of Rio de Janeiro, Brazil).

2.3.2. Cell Culture. MCF-7 cells were cultured in RPMI-1640 medium supplemented with fetal bovine serum (FBS) $10 \%$ as previously reported by Zingue et al. [23]. Briefly, cell cultures were also supplemented with penicillin $100 \mathrm{U} / \mathrm{mL}$, streptomycin $100 \mu \mathrm{g} / \mathrm{mL}$, and HEPES $10 \mathrm{mM}$. They were maintained at $37^{\circ} \mathrm{C}$ in a $\mathrm{CO}_{2} 5 \%$ humidified atmosphere and $\mathrm{pH} 7.4$. Every two days, cells were passaged by removing $90 \%$ of the supernatant and replaced by fresh medium. Viable cells (a minimum of 95\%) were checked at the beginning of the experiment by Trypan Blue dye exclusion test.

2.3.3. Cell Viability Assay. Cytotoxicity potential of L. acida extract was evaluated by Alamar Blue (resazurin) assay in MCF-7 cells as described in our previous report [24]. This assay evaluates the mitochondrial production as a measurement of cell viability. To evaluate the influence of concentration and time on cytotoxicity, $1 \times 10^{4}$ cells/well were seeded in a 96 -well plate in $100 \mu \mathrm{L}$ of culture medium. After $24 \mathrm{~h}$ to permit their adhesion, cells were exposed to L. acida extract at concentrations from 0.1 to $200 \mu \mathrm{g} / \mathrm{mL}$ for $24 \mathrm{~h}$. The $\mathrm{CC}_{50}$ (cytotoxic concentration, which means concentration 
required to reduce the cell number by 50\%) was determined by nonlinear regression analysis of the logarithm of concentration in function of the normalized response (percentage of cell viability) using the software GraphPad Prism 5.0. Each experiment was performed at least in triplicate and repeated three times.

2.3.4. E-Screen Assay. In order to evaluate estrogenic-like effects of $L$. acida extract a simple and sensitive E-screen cell proliferation assay was performed with MCF-7 cells. This assay indirectly determines the estrogenicity/antiestrogenicity of compounds through measurement of the proliferation of MCF-7 cells and was performed as previously described by Zingue et al. [23]. Briefly, cells were trypsinized and seeded in 24-well plates at an initial concentration of $5 \times 10^{4}$ cells per well in RPMI supplemented with FBS $10 \%$. After $24 \mathrm{~h}$ of incubation $\left(37^{\circ} \mathrm{C}, \mathrm{CO}_{2} 5 \%\right)$ to permit their adhesion, cells were washed with phosphate-buffered saline-PBS ( NaCl $137 \mathrm{mM}$; $\mathrm{KCl} 2.7 \mathrm{mM} ; \mathrm{Na}_{2} \mathrm{HPO}_{4} 10 \mathrm{mM} ; \mathrm{KH}_{2} \mathrm{PO}_{4} 1.8 \mathrm{mM}$; pH 7.4) and the Serum Replacement 2 (0.5x) supplemented phenol redfree RPMI was substituted for the seeding medium. A stock solution of $L$. acida ethanolic extract $100 \mathrm{mg} / \mathrm{mL}$ prepared in DMSO was then added to the experimental medium in order to reach concentrations from 0.1 to $200 \mu \mathrm{g} / \mathrm{mL}$. The DMSO concentration of $0.01 \%$ was fixed based on the final volume on different wells. For antiestrogenic evaluation, before cell incubation, $17 \beta$-estradiol $10 \mathrm{nM}$ was added to the wells. Cells treated with DMSO (0.01\%) and FBS $10 \%$ in RPMI served as solvent and medium controls, respectively. Quercetin (10 nM) was used as the reference/standard. The assay was stopped after $144 \mathrm{~h}$ by removing the medium from the wells, fixing the cells with cold trichloroacetic acid $10 \%$, and incubation at $4^{\circ} \mathrm{C}$ for $1 \mathrm{~h}$. Thereafter, cells were washed four times with tap water and dried. Cells were stained for $30 \mathrm{~min}$ with Sulforhodamine-B (SRB) $0.057 \%$ (w/v) which was dissolved in $1 \%$ acetic acid, rinsed four times with acetic acid $1 \%$, and air-dried. Bound dye was solubilized with Tris base $10 \mathrm{mM}$ $(\mathrm{pH} 10.5)$ in a shaker. Finally, aliquots were read in a Biotek EL800 absorbance reader (Winooski, USA) at $510 \mathrm{~nm}$. The results related to estrogenic activity were expressed as mean \pm standard error of the mean (SEM) of the proliferative effect (PE), which was calculated according to Schilirò et al. [25]: PE = max cell number of sample/cell number of DMSO control. The estrogenic activity of a sample was determined as the relative proliferative effect (RPE\%). The RPE compares the maximum proliferation induced by a sample with that induced by $17 \beta$-estradiol: $R P E \%=[P E$ for sample $/ P E$ for $17 \beta-$ estradiol] $\times 100[26]$.

\subsection{In Vivo Experiments}

2.4.1. Animals. Healthy female albinos Wistar rats (10-12 weeks old) weighing $\sim 150 \mathrm{~g}$ were supplied by the production facility of the Animal Physiology Laboratory, University of Yaounde 1 (Cameroon). All rats were housed in clean plastic cages at the room temperature and lit with natural light. They were given free access to tap water and free-soy rat chow. The composition of animal diet was corn (36.7\%), bone flour (14.5\%), wheat (36.6\%), fish flour (4.8\%), crushed palm kernel $(7.3 \%)$, sodium chloride $(0.3 \%)$, and vitamin complex (Olivitazol $\left.{ }^{\circledR}, 0.01 \%\right)$. All experiments were conducted in accordance with the principles and procedures of the European Union on Animal Care (CEE Council 86/609) guidelines adopted by the Cameroon Institutional National Ethic Committee, Ministry of Scientific Research and Technology Innovation (Reg. number FWA-IRD 0001954).

2.4.2. The 3-Day Uterotrophic Assay. The estrogenic activity of $L$. acida extract was evaluated using a classical 3-day uterotrophic assay in ovariectomized adult rats [27]. Thirty female Wistar rats were ovariectomized (OVX) under ketamine and valium anesthesia (10 mg/kg and $50 \mathrm{mg} / \mathrm{kg}$ BW i.p., resp.) and randomly grouped into six groups of five rats each, after 14 days of endogenous hormonal decline. The first group $(\mathrm{OVX})$ received $10 \mathrm{~mL} / \mathrm{kg}$ distilled water. The second group served as positive control and received $17 \beta$-estradiol valerate (E2V) at the dose of $1 \mathrm{mg} / \mathrm{kg} \mathrm{BW} /$ day. The four remaining groups were treated with $L$. acida ethanolic extract at the doses of 50, 100, 200, and $300 \mathrm{mg} / \mathrm{kg} \mathrm{BW}$. Animals were orally treated for 3 days; then vaginal smears were analyzed and animals were sacrificed by decapitation under light anesthesia (10 mg/kg BW diazepam and $50 \mathrm{mg} / \mathrm{kg}$ BW ketamine i.p.). Estrogen target organs (uterus, vagina, and mammary gland) were collected and fixed in 10\% formaldehyde for histomorphological analysis. Prior to the fixation, wet uteri were trimmed of fat and weighed. As endpoints, the uterine wet weight, uterine protein and glycogen levels, uterine water content, and uterine and vaginal epithelial heights as well as mammary gland alveolar and ductal structures were assessed.

2.4.3. The Postmenopausal-Rat Model of Osteoporosis. Twenty-five rats were either sham operated (Sham) or bilaterally ovariectomized (OVX) using the dorsal approach. Seven days later, animals were further distributed in five different groups $(n=5)$ and treated by gavage once daily (9:0010:00 a.m.) for 84 consecutive days as follows: Sham and one OVX group received vehicle (distilled water), while the third group received $1 \mathrm{mg} / \mathrm{kg}$ of E2V. The two further groups received $L$. acida extract at the doses of 50 and $200 \mathrm{mg} / \mathrm{kg}$ BW. Animals were weighed weekly. Twenty-four hours after the last administration and following a $12 \mathrm{~h}$ of overnight fasting, animals were sacrificed under light anesthesia. Blood samples were taken and centrifuged at $3500 \mathrm{rpm}(15 \mathrm{~min}$ at $\left.4^{\circ} \mathrm{C}\right)$ to obtain serum samples which were kept at $-15^{\circ} \mathrm{C}$ for the determination of alkaline phosphatase activity as well as inorganic phosphorus levels. The uterus, vagina, femur, tibia, third lumbar vertebrae (VL-3), mandible (the interradicular septum of the second molar) [28], liver, lungs, kidneys, stomach, adrenal, spleen, and heart were dissected out and cleaned of all soft tissues. Prior to immersion-fixation of organs in the $10 \%$ formaldehyde solution for histological analysis, they were weighted. Fresh bone (femur and tibia) volumes were measured using a plethysmometer and their density was calculated using the formula: density $=$ [bone wet weight $(\mathrm{kg}) \times 1000\left(\mathrm{~kg} / \mathrm{mm}^{3}\right) /$ volume of bone $\left.\left(\mathrm{mm}^{3}\right)\right]$ as described by Lee et al. [29]. After measuring the above parameters, bones were dried at $200^{\circ} \mathrm{C}$ for $24 \mathrm{~h}$ and weighed again. Further, they were calcined and the ashes obtained 
were dissolved in deionized water $(0.5 \mathrm{~g}$ per $2 \mathrm{~mL})$ and kept in $-15^{\circ} \mathrm{C}$ for the measurement of calcium and inorganic phosphorus content. The femur, VL-3, and mandible were successively fixed in $10 \%$ formalin for 1 week and decalcified in 10\% nitric acid [30] for histological analysis.

2.5. Cytological and Histological Analysis. Vaginal smears were taken using an eyedropper containing $10 \mathrm{~mL}$ of $\mathrm{NaCl}$ $0.9 \%$, placed on ringed slides, fixed in ethanol $95 \%$ for $30 \mathrm{~min}$, and stained with a Papanicolaou method [31]. Cellular types were observed under a light microscope using 400 magnifications. To determine the histomorphological changes in mammary gland, uterus, vagina, femur, VL-3, mandibular bone, liver, lungs, and kidneys, paraffin-embedded organs were cut to $5 \mu \mathrm{m}$ tissue sections and stained with hematoxylin and eosin. Stained sections were visualized and images captured using the complete Zeiss equipment consisting of a microscope Axioskop 40 connected to a computer where the images were transferred and analyzed with the MRGrab1.0 and Axio Vision 3.1 software, all provided by Zeiss (Hallbergmoos, Germany).

2.6. Biochemical Analysis. Total protein and glycogen levels in uteri were determined using the colorimetric method described by Gonal et al. [32] and Montgomery [33], respectively. The total calcium and inorganic phosphorus levels in bones were determined using reagent kits purchased from fortress Diagnostic (Muckamore, United Kingdom) and Human Gesellschaft (Germany). Serum alkaline phosphatase activity in serum was measured using reagent kits purchased from BIOLABO (Maizy, France).

For hematological analysis, white blood cell count, lymphocytes, monocytes, granulocytes, red blood cells (RBC) count, hematocrit $(\mathrm{Ht})$, hemoglobin $(\mathrm{Hb})$, mean corpuscular volume $(\mathrm{MCV})$, mean corpuscular hemoglobin $(\mathrm{MCH})$, mean corpuscular hemoglobin concentration (MCHC), and platelet count were evaluated using a Humacount $30^{\mathrm{TS}}$ Automated Hematology Analyzer from Human Diagnostics Worldwide (Wiesbaden, Germany).

2.7. Statistical Analysis. Results were presented as means \pm standard error of mean (SEM). In vitro experiments were performed in triplicate and repeated three times. All formulas and function were calculated with Microsoft Excel software. Data analysis was performed with GraphPad Prism 5.0 Software, using the ANOVA test followed by Dunnett's post hoc test. Differences were considered significant at a probability level of $5 \%(p<0.05)$.

\section{Results}

3.1. Results of Phytochemical Analyses. Preliminary phytochemical analysis showed that the ethanolic extract of stem bark of $L$. acida ethanolic possess phenols, flavonoids, saponins, tannins, and alkaloids. Quantitative phytochemical analysis of this extract revealed the quantity per $\mathrm{g}$ of dried extract of total phenols $(786.75 \pm 82.33)$, flavonoids (250.61 \pm 48.17), and alkaloids (31.64 \pm 5.63$)$ (Table 1).
TABLE 1: Quantitative analyses of selected phytochemicals present in L. acida ethanolextract.

\begin{tabular}{lcc}
\hline Number & Phytochemical class & Concentration in L. acida extract \\
\hline 1 & Total phenols & $786.75 \pm 82.33 \mathrm{mg}$ eq quercetin \\
2 & Flavonoids & $250.61 \pm 48.17 \mathrm{mg}$ eq quercetin \\
3 & Alkaloids & $31.64 \pm 5.63 \mathrm{mg}$ eq berberine \\
\hline
\end{tabular}

Total phenols and flavonoids are expressed in $\mathrm{mg}$ eq quercetin/g of dried extract while alkaloids content is expressed in $\mathrm{mg}$ eq berberine/g of dried extract. Data are represented as mean \pm SEM of triplicates from at least three independent experiments.

\subsection{In Vitro Estrogenicity Assessment}

3.2.1. Cytotoxicity. Ethanolic extract of Lannea acida did not induce cytotoxic effects in MCF-7 cells at tested concentrations (Figure 1(a)).

3.2.2. E-Screen Assay. Effects of L. acida ethanolic extract on MCF-7 cells proliferation are depicted in Figure 1(b). It can be observed that $17-\beta$ estradiol benzoate $(1 \mathrm{nM})$ and quercetin $(10 \mathrm{nM})$ induced a significant $(p<0.001)$ increase of MCF-7 cells yield. The $L$. acida ethanol extract induced a significant increase of MCF-7 cells yield at concentrations of $10(p<0.05), 100(p<0.05)$, and $200(p<0.01) \mu \mathrm{g} / \mathrm{mL}$ as compared to DMSO control. Further, a significant $(p<$ 0.001 ) and concentration-dependent antiestrogenic effect was noted with $L$. acida extract when administered with E2B.

\subsection{Results of the 3-Day Treatment with L. acida}

3.3.1. Effects on the Uterine Wet Weight and Uterine Content Parameters. As shown in Table 2, the 3-day oral administration of $L$. acida extract induced a significant increase in uterine wet weight and uterine water content at all tested doses as compared to OVX group. Similarly, the uterine total protein and glycogen levels significantly increased at all the tested doses except at the dose of $300 \mathrm{mg} / \mathrm{kg}$. The maximum increase was observed at the dose of $200 \mathrm{mg} / \mathrm{kg}$ BW; however, this increase remained much lower than in E2V-treated group.

3.3.2. Effects on the Uterine Epithelium. The 3-day treatment with the ethanolic extract of $L$. acida induced a significant $(p<0.05)$ increase in uterine epithelial height only at dose of $200 \mathrm{mg} / \mathrm{kg} \mathrm{BW}$ (from $3.17 \pm 0.21$ to $3.87 \pm 0.22 \mu \mathrm{m}$ ). However this increase remained much lower than that induced by E2V at the dose of $1 \mathrm{mg} / \mathrm{kg} \mathrm{BW}$, which showed a 3-fold $(p<0.001)$ increase of uterine epithelial height (Figure 2(b)). The photomicrographs of uteri of OVX animals showed a low cuboidal epithelium, while in the E2V treated group, all structures are hypertrophic; the endometrium is lined by tall columnar cells with squamous metaplasia and atypic mitotic pattern surrounded by anaplastic epithelial nuclei (Figure 2(a)). Microphotographs of uteri of animals receiving L. acida ethanol extract at the dose of $200 \mathrm{mg} / \mathrm{kg}$ displayed an endometrium consisting of tall cuboidal single-layered epithelial cells with abundant mitotic figures and necrosis; 


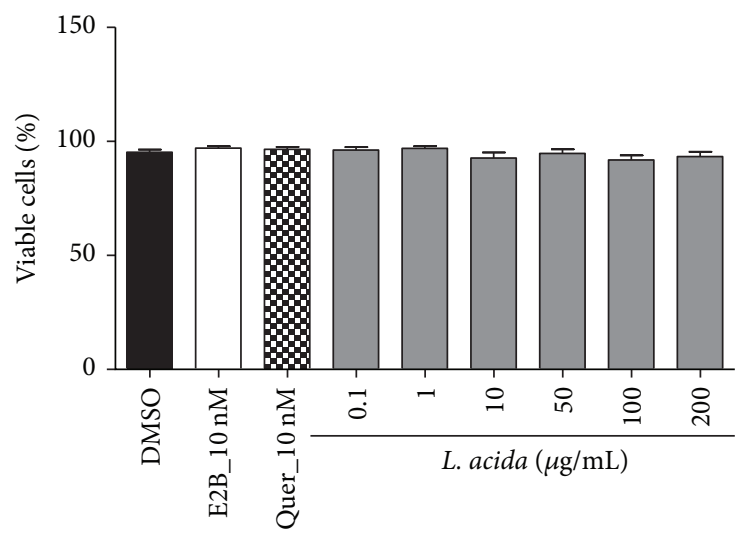

(a)

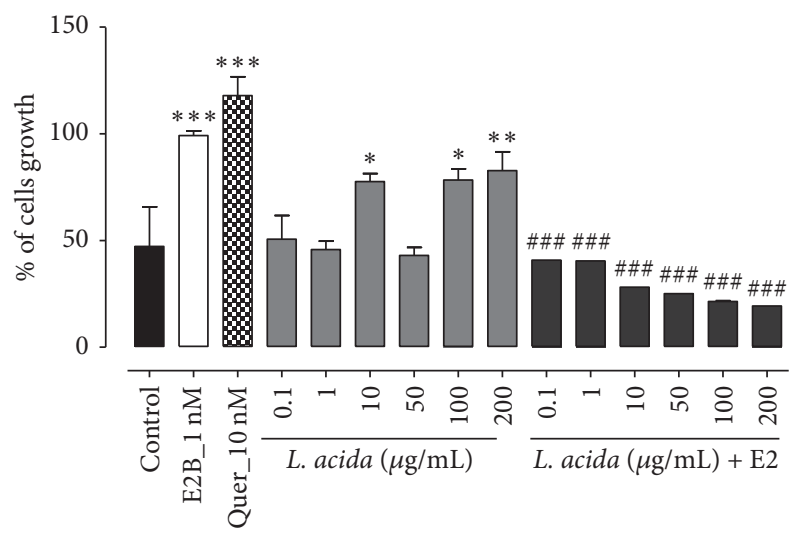

(b)

FIGURE 1: Effects of L. acida ethanol extract on MCF-7 cells proliferation viability (a) and growth (b). Its effect was investigated by measuring E-screen assay. The relative MCF-7 cells yields (PE) were measured in the presence of DMSO (0.01\%), $17 \beta$-estradiol benzoate (E2B, $10 \mathrm{nM})$, quercertin $\left(10 \mathrm{nM}\right.$ ), and $L$. acida extract (from 0.1 to $200 \mu \mathrm{g} / \mathrm{mL}$ ). PE = max cell number of sample/cell number of DMSO control; ${ }^{*} p<0.05$, ${ }^{* *} p<0.01$ and $^{* * *} p<0.001$ as compared to the DMSO control. ${ }^{\# \#} p<0.001$ as compared to the E2B control.

TABLE 2: Effects of the ethanol extract of Lannea acida on uterus.

\begin{tabular}{lcccc}
\hline Groups & $\begin{array}{c}\text { Uterine wet weight } \\
(\mathrm{mg} / \mathrm{kg})\end{array}$ & $\begin{array}{c}\text { Water content in uterus } \\
\text { WW/DW }\end{array}$ & $\begin{array}{c}\text { Total protein levels in uterus } \\
(\mathrm{mg} / \mathrm{mL})\end{array}$ & $\begin{array}{c}\text { Glycogen level in uterus } \\
(\mathrm{mg} / \mathrm{mL})\end{array}$ \\
\hline OVX & $298.75 \pm 33.55$ & $0.13 \pm 0.014$ & $0.1087 \pm 0.0002$ & $5.43 \pm 0.11$ \\
E2V & $2022.63 \pm 91.81^{* * *}$ & $0.41 \pm 0.058^{* * *}$ & $0.1114 \pm 0.0003^{* *}$ & $9.21 \pm 0.21^{* *}$ \\
Lannea acida $(\mathrm{mg} / \mathrm{kg})$ & & & & \\
50 & $507.64 \pm 10.42^{* *}$ & $0.20 \pm 0.008^{*}$ & $0.1096 \pm 0.0003^{*}$ & $6.71 \pm 0.42^{*}$ \\
100 & $424.73 \pm 37.48^{*}$ & $0.31 \pm 0.025^{* *}$ & $0.1095 \pm 0.0002^{*}$ & $7.3 \pm 0.25^{*}$ \\
200 & $553.38 \pm 43.72^{* *}$ & $0.29 \pm 0.036^{* *}$ & $0.1105 \pm 0.0001^{* *}$ & $6.9 \pm 0.53^{*}$ \\
300 & $424.69 \pm 31.48^{*}$ & $0.23 \pm 0.032^{*}$ & $0.1090 \pm 0.0002$ & $6.11 \pm 0.3$ \\
\hline
\end{tabular}

OVX = ovariectomized animals that received the vehicle (distilled water); E2V = OVX animals treated with $1 \mathrm{mg} / \mathrm{kg}$ of $17 \beta$-estradiol valerate; Lannea acida $=$ OVX animals treated with ethanol extract of Lannea acida at doses of 50, 100, 200, and $300 \mathrm{mg} / \mathrm{kg} \mathrm{BW}$. WW = wet weight; DW = dried weight. Data are expressed as mean $\pm \operatorname{SEM}(n=5) ;{ }^{*} p<0.05,{ }^{* *} p<0.01$, and ${ }^{* * *} p<0.001$ as compared to the OVX group.

however, this effect is less than those observed in E2V-treated group.

3.3.3. Effects on Vagina. As depicted in Figure 3(a) vaginal smears of controls (OVX) had predominantly parabasal and polynuclear cells, corresponding to diestrus. On the other hand, smears of animals treated with E2V and L. acida extract at all tested doses suggest that they are in estrus, evidenced by the presence of superficial cells (Figure 3(a)). Furthermore, the microphotographs of vaginal epithelium of the control group (OVX) consist simply of the stratum germinativum $(\mathrm{Ge})$ at the lowest level of approximately the thickness of three to seven cells. After the treatment with E2V $(1 \mathrm{mg} / \mathrm{kg})$, the vaginal epithelium became stratified characterized by the presence of stratum germinativum, stratum granulosum $(\mathrm{Gg})$, and stratum corneum (Co) (Figure 3(b)). Following the $L$. acida extract treatment, the vaginal epithelium became hypertrophic and hyperplasic; however compared to E2V there are fewer cell layers and it failed to induce a cornification.

The graphical representation of the vaginal epithelial height (Figure 4) shows that E2V induced a 5-fold ( $p<$ 0.001 ) increase of vaginal epithelial height. $L$. acida ethanolic extract significantly $(p<0.01)$ and in a bell shaped dose response manner increased vaginal epithelial height. The maximum 2.8-fold increment was obtained with the dose of $100 \mathrm{mg} / \mathrm{kg} \mathrm{BW}$ (from $3.03 \pm 0.04$ to $8.6 \pm 0.92 \mu \mathrm{m}$ ) as compared to the OVX group.

3.3.4. Effects on Mammary Glands. Figure 5 presents sections of mammary glands. Ovariectomy induced an atrophy of mammary glands materialized in OVX-histological sections by a modest alveolar development, a small cluster of densely packed epithelial cells without luminal formation, the loss of the gland parenchyma $(\mathrm{Tc})$, and the ductular and alveolar components, while adipocyte tissue (At) appears prominent. Mammary glands of E2V-treated group present well-formed acinar and luminal structures, an increase in proliferative activity compared to OVX group such as increase of the diameter and the lumen of alveoli, abundant eosinophil secretion (Se) in lumen of alveoli, and further compression of stromal fat. Similar changes were observed following a 3-day treatment with $L$. acida extract at all tested doses but only doses of 200 and $300 \mathrm{mg} / \mathrm{kg}$ BW presented an eosinophil secretion in their lumens. 


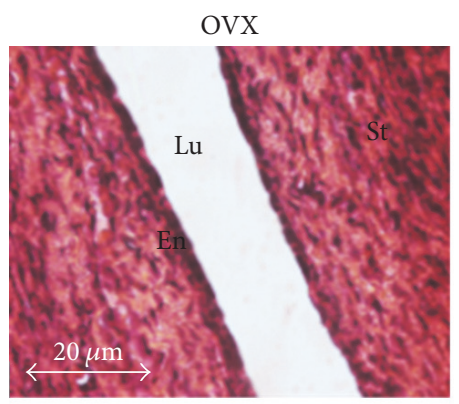

LA 100

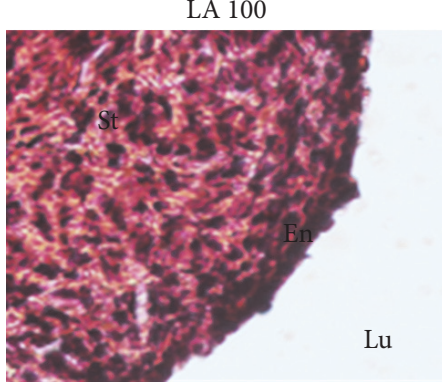

$\mathrm{Lu}$

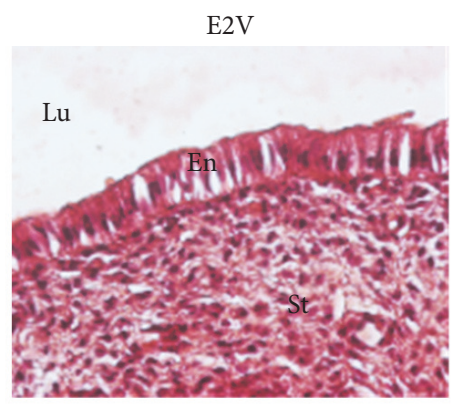

LA 200

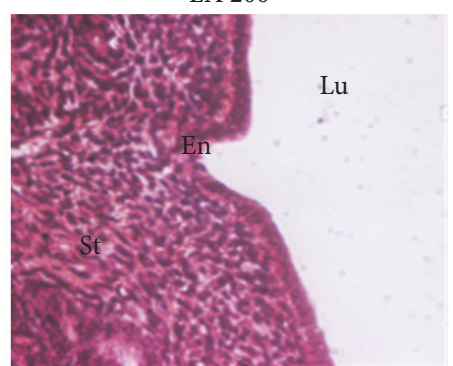

(a)

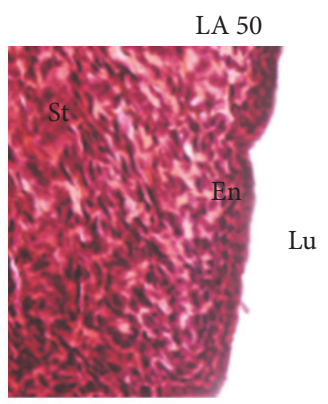

LA 300

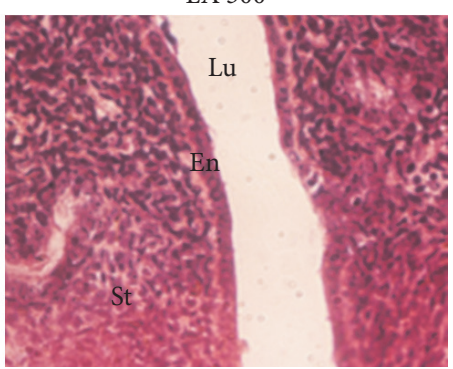

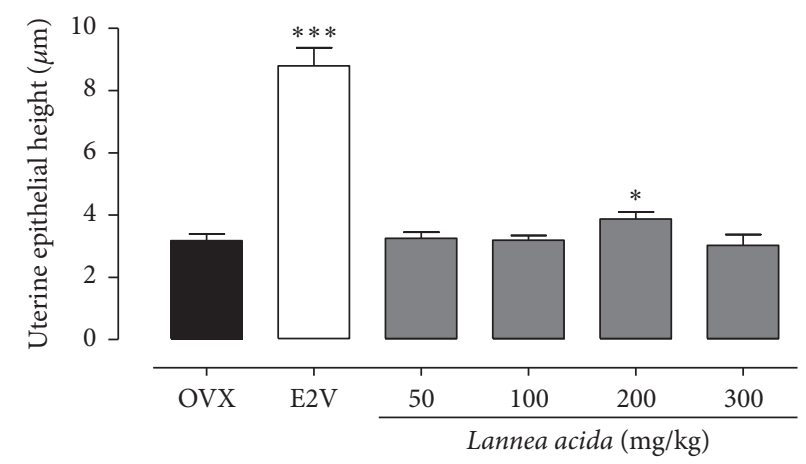

(b)

FIGURE 2: Effects of a 3-day treatment with L. acida ethanol extract on microphotographs (hematoxylin-eosin staining, 400x) (a) and graphical representation of uterine epithelial height (b). OVX $=\mathrm{OVX}$ animals treated with distilled water as vehicle; $\mathrm{E} 2 \mathrm{~V}=\mathrm{OVX}$ animals treated with $17 \beta$-estradiol valerate at $1 \mathrm{mg} / \mathrm{kg}$ BW; Lannea acida $=$ OVX animals treated with L. acida ethanol extract at doses of 50, 100, 200, and 300 mg $/ \mathrm{kg}$ BW. ${ }^{*} p<0.05$ and $^{* * *} p<0.001$ as compared with OVX control. Lu: uterine lumen; En: endometrium; St: stroma.

TABLE 3: Effects of the ethanol extract of Lannea acida on estrogen target organs in postmenopausal-rat model after 12 weeks of treatment.

\begin{tabular}{|c|c|c|c|c|c|}
\hline \multirow{3}{*}{ Items } & \multirow{3}{*}{ Sham } & \multicolumn{4}{|c|}{ Ovariectomized rats } \\
\hline & & \multirow{2}{*}{ OVX } & \multirow{2}{*}{$\mathrm{E} 2 \mathrm{~V}$} & \multicolumn{2}{|c|}{ Lannea acida (mg/kg BW) } \\
\hline & & & & 50 & 200 \\
\hline Uterine wet weight (mg/kg) & $1761.34 \pm 174.20$ & $248.03 \pm 19.56^{\# \# \#}$ & $1970.98 \pm 203.67^{* *}$ & $226.36 \pm 16.22$ & $277.37 \pm 17.63$ \\
\hline Uterine epithelial height $(\mu \mathrm{m})$ & $9.88 \pm 0.29$ & $2.02 \pm 0.06^{\# \# \#}$ & $10.05 \pm 1.29^{* *}$ & $5.79 \pm 1.75^{*}$ & $2.79 \pm 0.19$ \\
\hline Vaginal epithelial height $(\mu \mathrm{m})$ & $21.83 \pm 1.82$ & $4.20 \pm 0.29^{\# \#}$ & $46.01 \pm 0.85^{* *}$ & $5.98 \pm 0.29$ & $6.38 \pm 0.35$ \\
\hline
\end{tabular}

Sham (sham operated) and OVX (ovariectomized) animals received the vehicle (distilled water); E2V = OVX animals treated with $1 \mathrm{mg} / \mathrm{kg}$ of $17 \beta$-estradiol valerate; Lannea acida $=$ OVX animals treated with ethanol extract of Lannea acida at doses of 50 and $200 \mathrm{mg} / \mathrm{kg}$ BW. Data are expressed as mean \pm SEM $(n=$ 5); ${ }^{*} p<0.05$ and ${ }^{* *} p<0.01$ as compared to the OVX group. ${ }^{\# \#} p<0.001$ as compared to the Sham group.

\subsection{Results of the 84-Day Treatment with L. acida}

3.4.1. Effects on Estrogen Target Organs. As depicted in Table 3, bilaterally oophorectomy significantly $(p<0.001)$ decreased the uterine wet weight $(610.13 \%)$ and uterine (388.57\%) and vaginal (419.4\%) epithelial height as compared to the Sham operated group. Following E2V treatment, the uterine wet weight (694.65\%) and the uterine (397.39\%) and vaginal (419.4\%) epithelial height increased as compared to OVX group. L. acida extract induced a slight but significant $(p<0.05)$ increase of uterine epithelial height at the dose of $50 \mathrm{mg} / \mathrm{kg}$ BW (30.82\%) compared to OVX control. 


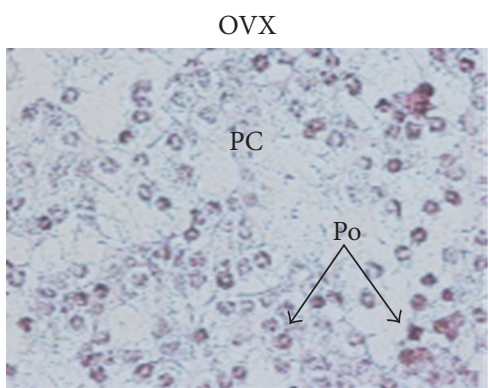

LA 100
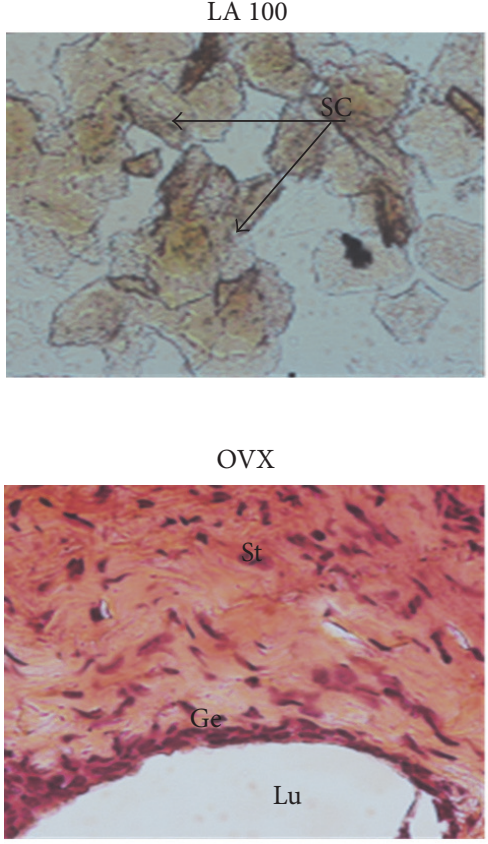

LA 100

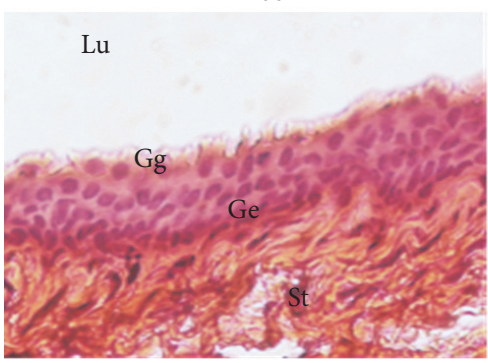

$\mathrm{E}_{2} \mathrm{~V}$

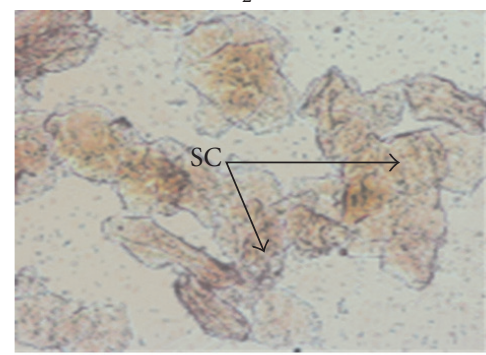

LA 200

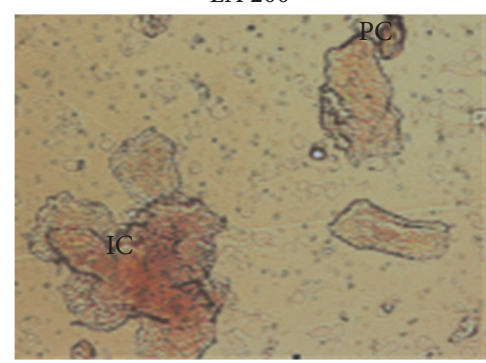

(a)

$\mathrm{E}_{2} \mathrm{~V}$

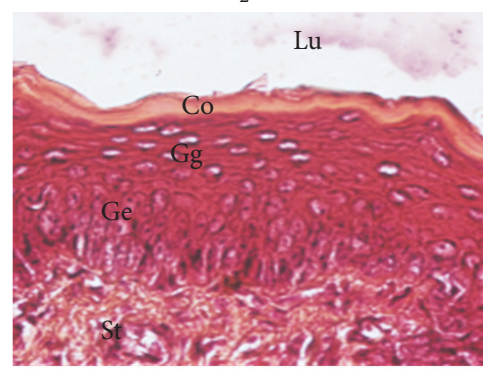

LA 200

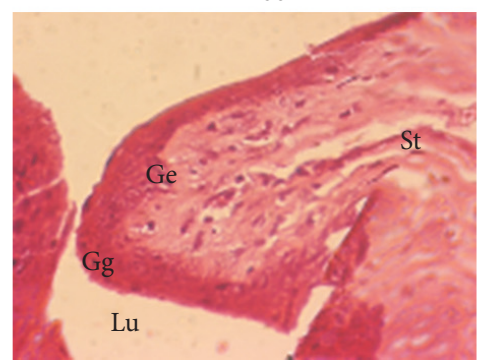

(b)

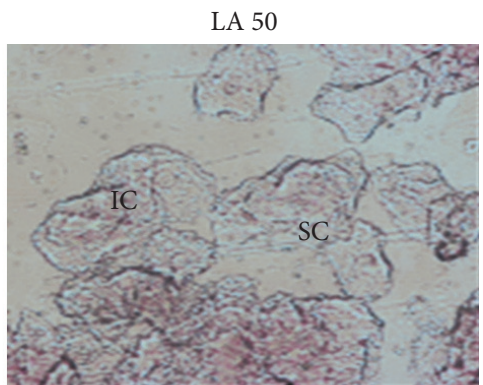

LA 300

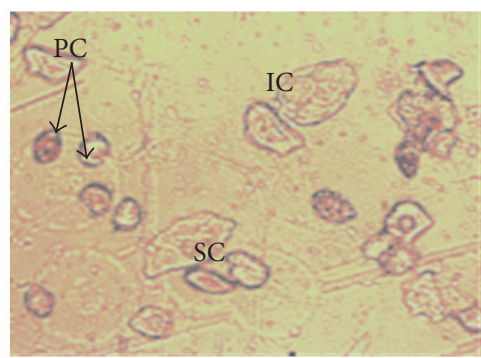

LA 50

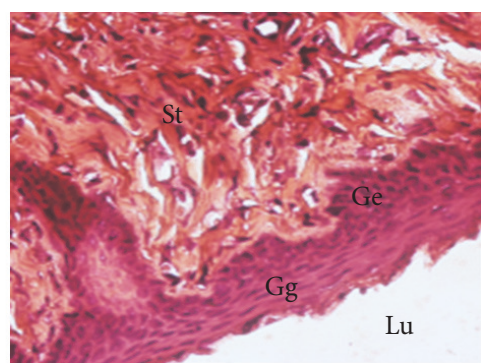

LA 300

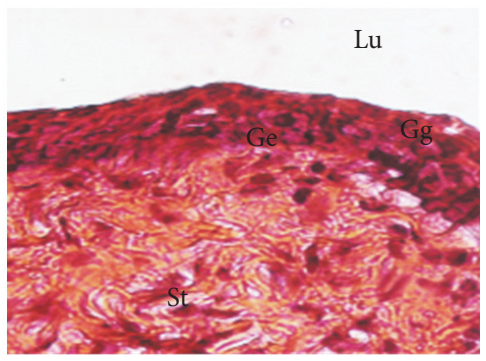

FIGURE 3: Effects of a 3-day treatment with L. acida ethanol extract on the vaginal epithelium: smear (Papanicolaou staining, 400x) (a) and microphotographs (hematoxylin-eosin staining, 400x). OVX = OVX animals treated with distilled water as the vehicle; E2V = OVX animals treated with $17 \beta$-estradiol valerate at $1 \mathrm{mg} / \mathrm{kg}$ BW; Lannea acida $=$ OVX animals treated with L. acida ethanol extract at doses of 50, 100, 200, and $300 \mathrm{mg} / \mathrm{kg}$ BW. $\mathrm{Po}=$ polynuclear cells, $\mathrm{PC}=$ parabasal cells, $\mathrm{IC}=$ intermediate cells, $\mathrm{SP}=$ superficial cells, $\mathrm{Lv}=$ vaginal lumen, $\mathrm{Co}=$ stratum corneum, $\mathrm{Gg}=$ stratum granulosum, $\mathrm{Ge}=$ stratum germinativum, and $\mathrm{St}$ : stroma.

3.4.2. Effects on Bone Weight and Density. As shown in Figure 6 ovariectomy induced a significant decrease in femur $(p<0.05)$ and tibia $(p<0.001)$ wet weight (Figures 6(a) and $6(\mathrm{~b}))$ and a significant $(p<0.05)$ decrease of dried femur and tibia weight as well as the femur $(33.78 \%, p<$ $0.01)$ and tibia $(38.83 \%, p<0.001)$ densities as compared to sham operated rats. E2V and L. acida extract at the dose of $200 \mathrm{mg} / \mathrm{kg}$ induced a significant $(p<0.05)$ increase of femur and tibia wet and dried weights as compared to OVX group. Furthermore, significant $(p<0.05)$ increases of femur and tibia densities were also observed following administration of E2V and L. acida extract at the dose of $200 \mathrm{mg} / \mathrm{kg}$ as compared to OVX (Figures 6(e) and 6(f)).

3.4.3. Effects on Body and Organ Weights. After 84 days of treatment period, a significant $(p<0.05)$ increase of body 
TABLE 4: Effects of L. acida ethanol extract on body weight and relative organ weights after 12 weeks of treatment in postmenopausal-rat model.

\begin{tabular}{|c|c|c|c|c|c|}
\hline \multirow{3}{*}{ Items } & \multirow{3}{*}{ Sham } & \multicolumn{4}{|c|}{ Ovariectomized rats } \\
\hline & & \multirow{2}{*}{ OVX } & \multirow{2}{*}{ E2V } & \multicolumn{2}{|c|}{ Lannea acida (mg/kg BW) } \\
\hline & & & & 50 & 200 \\
\hline \multicolumn{6}{|c|}{ Body weight (g) } \\
\hline Initial & $155.80 \pm 5.67$ & $145.80 \pm 2.75$ & $147.00 \pm 4.49$ & $153.60 \pm 4.43$ & $146.10 \pm 5.23$ \\
\hline Final & $182.10 \pm 8.51$ & $203.10 \pm 3.22^{\#}$ & $185.17 \pm 5.13$ & $199.74 \pm 6.17^{\#}$ & $183.14 \pm 7.79$ \\
\hline \multicolumn{6}{|c|}{ Organ weights ( $m g / k g)$} \\
\hline Liver & $32283.86 \pm 845.01$ & $30918.79 \pm 701.81$ & $31590.70 \pm 948.29$ & $31055.44 \pm 905.08$ & $28137.84 \pm 1924.21$ \\
\hline Lungs & $7648.59 \pm 166.14$ & $8525.59 \pm 243.24$ & $7834.56 \pm 374.67$ & $8799.39 \pm 472.94$ & $11380.12 \pm 1053.63^{* *}$ \\
\hline Kidneys & $5013.12 \pm 107.64$ & $5127.95 \pm 59.69$ & $5366.69 \pm 284.57$ & $5105.20 \pm 171.53$ & $5989.34 \pm 275.03^{*}$ \\
\hline Stomach & $10569.99 \pm 277.86$ & $11892.14 \pm 761.88$ & $12379.29 \pm 848.28$ & $12554.57 \pm 1102.40$ & $13042.20 \pm 1229.32$ \\
\hline Spleen & $3442.94 \pm 82.54$ & $3196.14 \pm 67.20$ & $3526.94 \pm 324.13$ & $3626.61 \pm 135.77$ & $3618.77 \pm 166.85$ \\
\hline Adrenals & $392.17 \pm 147.31$ & $211.02 \pm 27.70$ & $221.09 \pm 24.89$ & $213.17 \pm 5.20$ & $197.70 \pm 11.40$ \\
\hline Heart & $3119.72 \pm 24.16$ & $3432.90 \pm 120.48$ & $3194.82 \pm 151.18$ & $3475.69 \pm 166.82$ & $3527.98 \pm 36.96$ \\
\hline
\end{tabular}

Sham (sham operated) and OVX (ovariectomized) animals received the vehicle (distilled water); E2V = OVX animals treated with $1 \mathrm{mg} / \mathrm{kg}$ of $17 \beta$-estradiol valerate; Lannea acida $=$ OVX animals treated with ethanol extract of Lannea acida at doses of 50 and $200 \mathrm{mg} / \mathrm{kg}$ BW. Data are expressed as mean \pm SEM $(n=$ 5); ${ }^{*} p<0.05$ and $^{* *} p<0.01$ as compared to the OVX group. ${ }^{*} p<0.01$, initial body weight compared to the final one.

TABLE 5: Effects of Lannea acida ethanol extract after 12 weeks of oral treatment in some biomarkers of osteoporosis.

\begin{tabular}{|c|c|c|c|c|c|}
\hline \multirow{3}{*}{ Items } & \multirow{3}{*}{ Sham } & \multicolumn{4}{|c|}{ Ovariectomized rats } \\
\hline & & \multirow{2}{*}{ OVX } & \multirow{2}{*}{$\mathrm{E} 2 \mathrm{~V}$} & \multicolumn{2}{|c|}{ Lannea acida (mg/kg BW) } \\
\hline & & & & 50 & 200 \\
\hline Alkaline phosphatase (UI/L) & $5.03 \pm 0.456$ & $8.72 \pm 0.618^{* * *}$ & $6.86 \pm 0.377^{*}$ & $5.63 \pm 0.096^{* * *}$ & $7.56 \pm 0.330$ \\
\hline \multicolumn{6}{|l|}{ Calcium $(\mathrm{mmol} / \mathrm{L})$} \\
\hline Tibia & $0.045 \pm 0.007$ & $0.028 \pm 0.003$ & $0.050 \pm 0.011$ & $0.038 \pm 0.004$ & $0.028 \pm 0.005$ \\
\hline Femur & $0.03 \pm 0.004$ & $0.028 \pm 0.002$ & $0.025 \pm 0.006$ & $0.032 \pm 0.002$ & $0.043 \pm 0.005^{*}$ \\
\hline \multicolumn{6}{|c|}{ Inorganic phosphorus (mmol/L) } \\
\hline Tibia & $7.24 \pm 0.622$ & $2.88 \pm 0.122^{* * *}$ & $3.99 \pm 0.347$ & $3.23 \pm 0.756$ & $4.64 \pm 0.344^{*}$ \\
\hline Femur & $3.99 \pm 0.540$ & $2.85 \pm 0.384$ & $4.93 \pm 0.697^{*}$ & $2.72 \pm 0.182$ & $4.30 \pm 0.482^{*}$ \\
\hline
\end{tabular}

Sham (sham operated) and OVX (ovariectomized) animals received the vehicle (distilled water); E2V = OVX animals treated with $1 \mathrm{mg} / \mathrm{kg}$ of estradiol valerate; Lannea acida $=$ OVX animals treated with ethanol extract of Lannea acida at doses of 50 and $200 \mathrm{mg} / \mathrm{kg}$ BW. Data are expressed as mean \pm SEM $(n=5)$; ${ }^{*} p<0.05$ and ${ }^{* * *} p<0.001$ as compared to the OVX group.

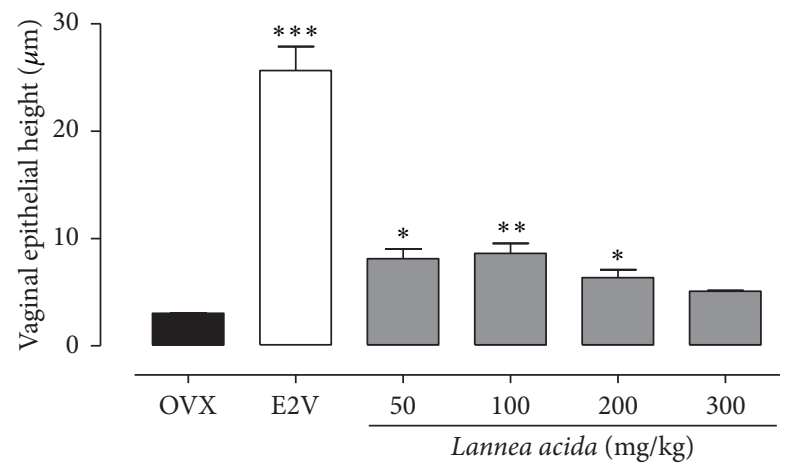

FIGURE 4: Effects of a 3-day treatment with L. acida ethanol extract on the vaginal epithelial height. OVX = OVX animals treated with distilled water as the vehicle; $\mathrm{E} 2 \mathrm{~V}=\mathrm{OVX}$ animals treated with $17 \beta$-estradiol valerate at $1 \mathrm{mg} / \mathrm{kg} \mathrm{BW}$; Lannea acida $=$ OVX animals treated with $L$. acida ethanol extract at doses of 50, 100, 200, and $300 \mathrm{mg} / \mathrm{kg}$ BW. ${ }^{*} p<0.05,{ }^{* *} p<0.01$, and ${ }^{* * *} p<0.001$ as compared with OVX control. weight was observed in OVX and L. acida extract (50 mg/kg) groups (Table 4). The E2V and L. acida extract at the dose of $200 \mathrm{mg} / \mathrm{kg}$ treatments prevented this body weight increase.

The different treatments did not induce change in the organ wet weights, except the relative weights of lungs and kidneys that increased following the 84-day treatment with L. acida extract at the dose of $200 \mathrm{mg} / \mathrm{kg}$.

3.4.4. Biochemical Bone Parameters. Table 5 shows the effects of $L$. acida extract or $\mathrm{E} 2 \mathrm{~V}$ treatment on serum and bone biochemical parameters. Ovariectomized rats showed a significant increase $(42.29 \%$; $p<0.001)$ in the serum alkaline phosphatase (ALP) activity as compared to Sham rats. E2V treatment significantly decreased $(21.29 \%, p<0.05)$ the ALP activity as compared to the OVX controls. The L. acida ethanol extract induced a similar effect by decreasing ALP activity at all tested doses, although being only significant at the dose of $50 \mathrm{mg} / \mathrm{kg} \mathrm{BW} /$ day $(31.49 \%, p<0.001)$. 


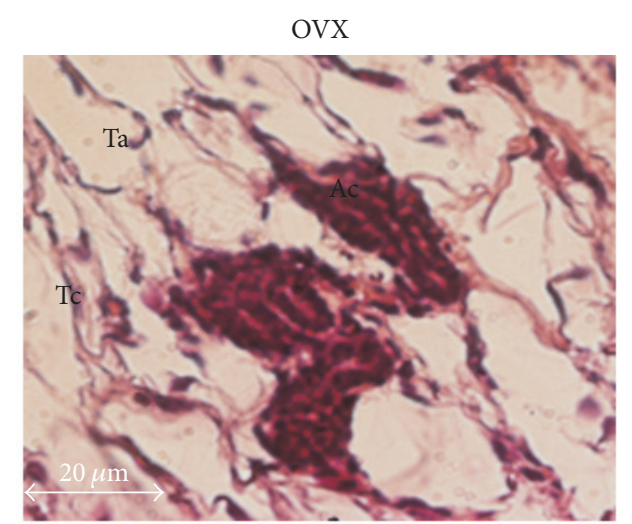

LA 50

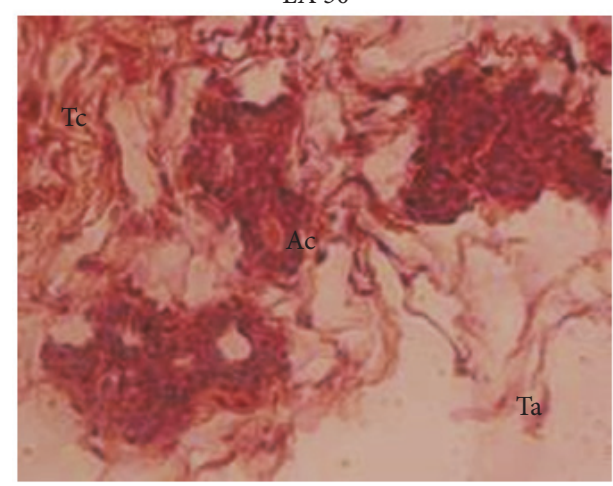

LA 200

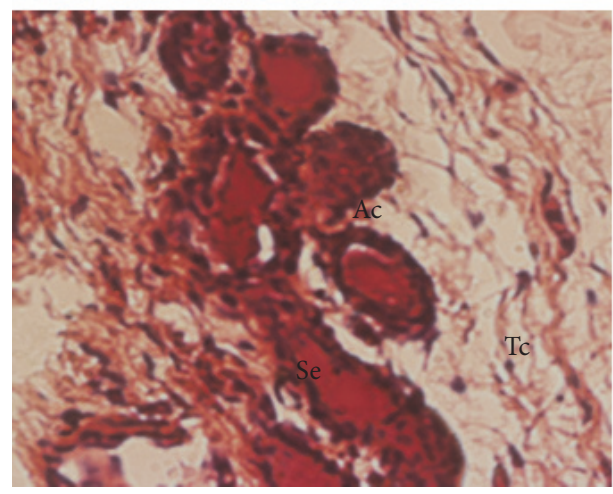

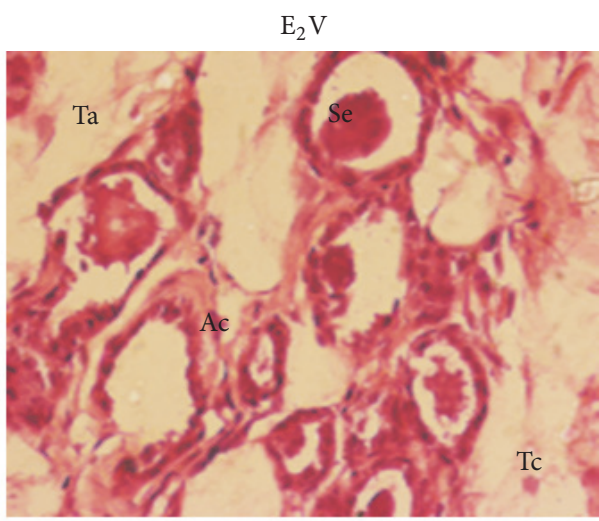

LA 100

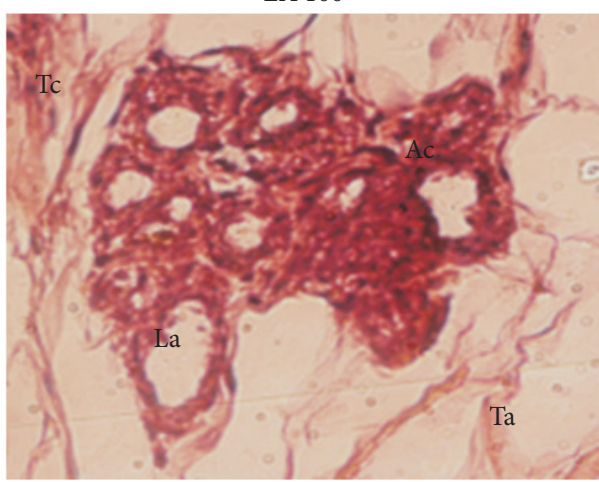

LA 300

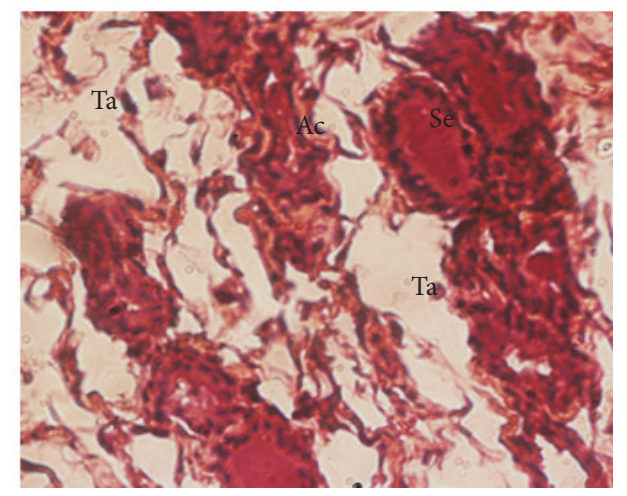

FIGURE 5: Effects of a 3-day treatment with L. acida ethanol extract on mammary glands: microphotographs of hematoxylin-eosin staining $(400 \mathrm{x})$. OVX $=$ OVX animals treated with distilled water as the vehicle; E2V $=$ OVX animals treated with $17 \beta$-estradiol valerate at $1 \mathrm{mg} / \mathrm{kg}$ BW; LA = OVX animals treated with L. acida ethanol extract at doses of 50, 100, 200, and $300 \mathrm{mg} / \mathrm{kg} \mathrm{BW.} \mathrm{La} \mathrm{=} \mathrm{lumen} \mathrm{of} \mathrm{alveoli;} \mathrm{Ep} \mathrm{=} \mathrm{alveoli}$ epithelium; At = adipose tissue; $\mathrm{Se}=$ eosinophil secretion.

Concerning calcium levels in tibia and femur, no significant changes were observed between OVX, Sham, and E2V groups. However, a significant $(p<0.05)$ increase in the calcium level was observed in rats treated with $L$. acida $200 \mathrm{mg} / \mathrm{kg}$ as compared to OVX control.

Regarding inorganic phosphorus (IP) levels in tibia and femur ashes, a decrease of IP in tibia $(p<0.001)$ and femur (nonsignificant) was observed in OVX rats as compared to sham operated controls. E2V treatment significantly $(73.03 \%$, $p<0.05)$ increased IP in femur compared to OVX controls. Treatment with $L$. acida extract increased $(p<0.05)$ IP levels in femur $(50.86 \%)$ and in tibia (61.27\%) ashes at the dose of $200 \mathrm{mg} / \mathrm{kg}$.
3.4.5. Effects on the Hematological Parameters. Lymphocytes, red blood cell count, and hemoglobin level as well as hematocrit increased in ovariectomized rats as compared to sham operated rats after 84 days of experimentation although these values remain in the normal ranges (Table 6). The E2V-treatment prevented this blood cell increment, although being significant only in the hematocrit parameter. $L$. acida extract also protected rat against the ovariectomy-induced increase in blood cells, evidenced by a significant reduction of lymphocytes, granulocyte, hemoglobin level, and hematocrit.

3.4.6. Effects on the Microarchitecture of Some Organs. No alterations in the microarchitecture of liver, lungs, and 


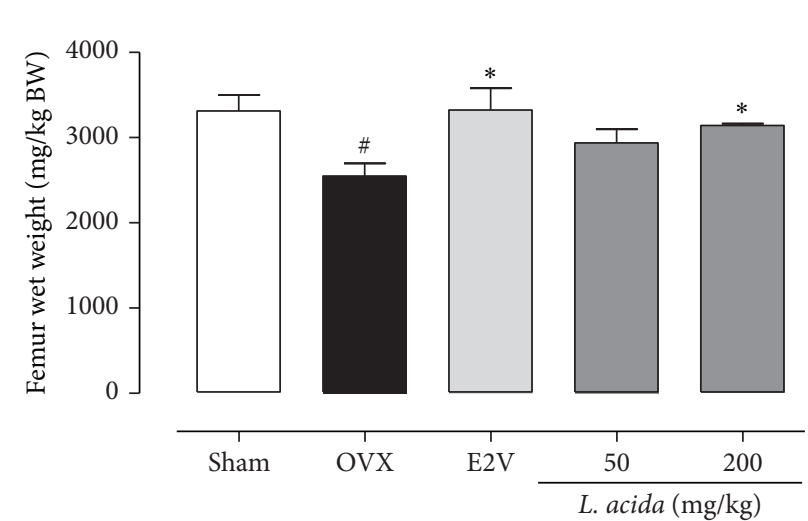

(a)

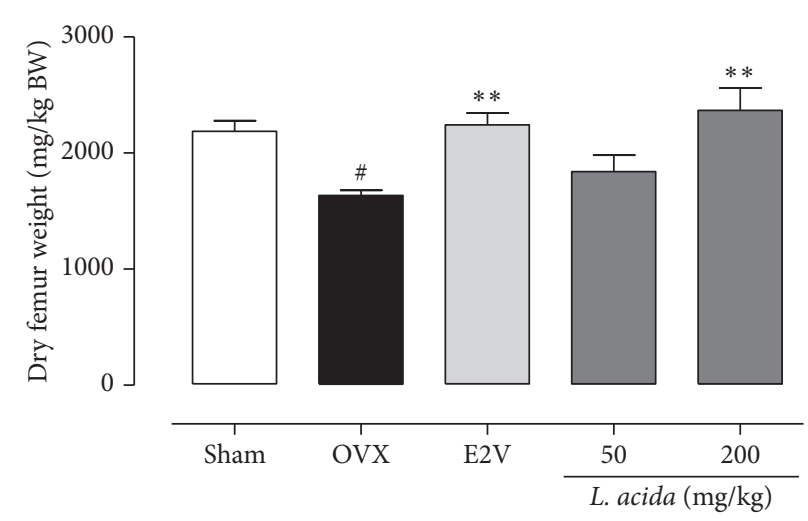

(c)

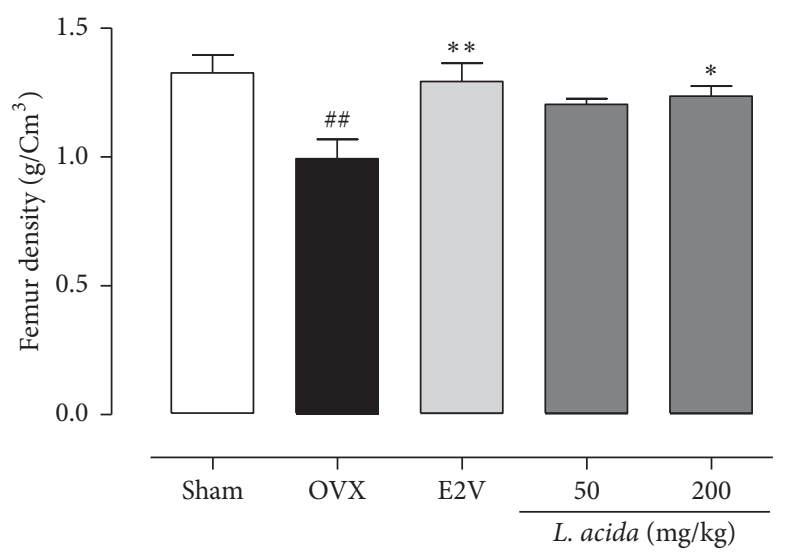

(e)

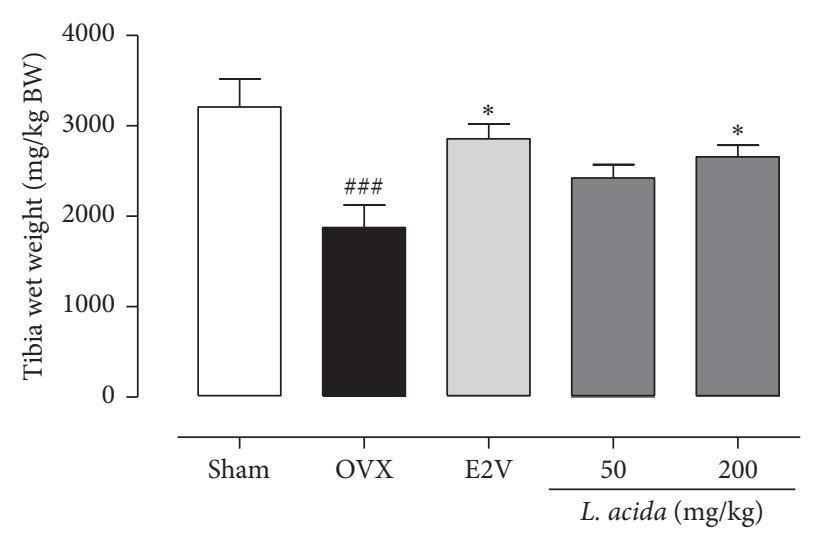

(b)

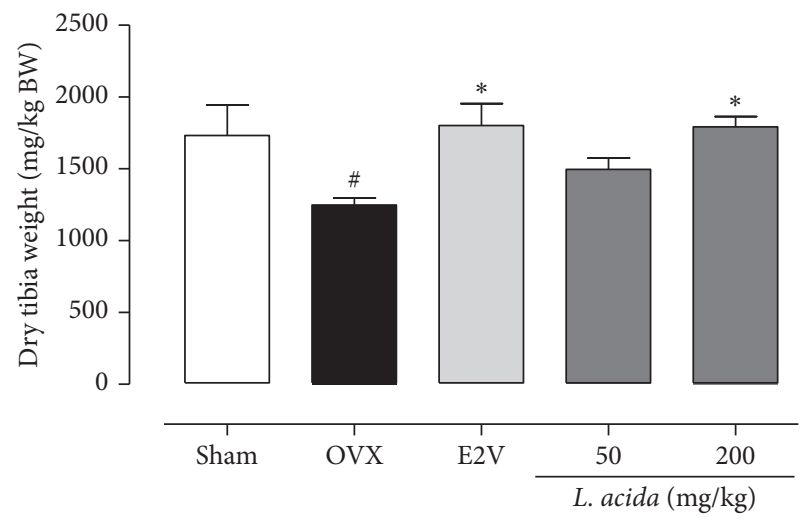

(d)

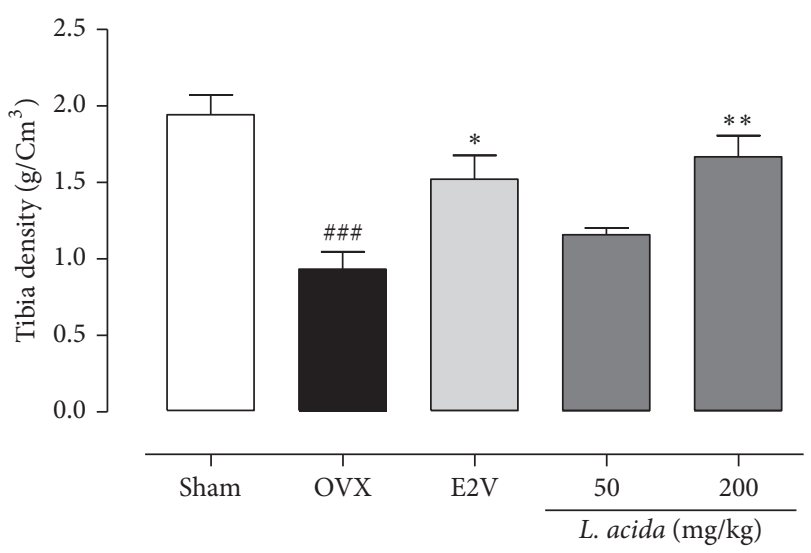

(f)

Figure 6: Protective effects of L. acida ethanol extract on bone loss: in both femur and tibia wet weight ((a) and (b)), dried weight ((c) and (d)), and density ((e) and (f)). Sham (sham operated) and OVX (ovariectomized) animals received the vehicle (distilled water). E2V = OVX animals treated with $1 \mathrm{mg} / \mathrm{kg}$ of $17 \beta$-estradiol valerate; Lannea acida $=\mathrm{OVX}$ animals treated with ethanol extract of Lannea acida at doses of 50 and $200 \mathrm{mg} / \mathrm{kg} \mathrm{BW}$. Data are expressed as mean \pm SEM $(n=5) .{ }^{*} p<0.05$ and ${ }^{* *} p<0.01$ compared with control; ${ }^{\#} p<0.05$, ${ }^{\# *} p<0.01$, and $^{\# \# \#} p<0.001$ compared with Sham.

kidneys were noted in this work (Figure 7). However, the femur, tibia, VL-3, and mandible microarchitectures of OVX rats showed bone marrow disparities into the trabecular network (Figure 8). E2V and L. acida ethanol extract $(200 \mathrm{mg} / \mathrm{kg})$ treatments prevented bone resorption, evidenced by the inhibition of bone marrow loss into the trabecular network.

\section{Discussion}

The present work aimed to investigate the estrogenic and bone loss preventive effects of the ethanol extract of Lannea acida, a plant used in the Cameroonian traditional system to treat many ailments including gynaecological problems and rheumatism. To evaluate the in vitro estrogenic effect of $L$. 
TABLE 6: Effects of Lannea acida ethanol extract on hematological parameters after 11 weeks of treatment in postmenopausal-rat model.

\begin{tabular}{|c|c|c|c|c|c|c|}
\hline \multirow{3}{*}{ Items } & \multirow{3}{*}{ Normal ranges } & \multirow{3}{*}{ Sham } & \multicolumn{4}{|c|}{ Ovariectomized rats } \\
\hline & & & \multirow{2}{*}{ OVX } & \multirow{2}{*}{$\mathrm{E} 2 \mathrm{~V}$} & \multicolumn{2}{|c|}{ Lannea acida (mg/kg BW) } \\
\hline & & & & & 50 & 200 \\
\hline $\mathrm{WBC}\left(10^{3} / \mu \mathrm{L}\right)$ & $5-16$ & $4.02 \pm 0.42$ & $4.00 \pm 0.21$ & $5.62 \pm 0.80$ & $2.48 \pm 0.14$ & $5.58 \pm 0.54$ \\
\hline Lymphocytes (\%) & $65-85$ & $74.42 \pm 1.77$ & $83.06 \pm 0.46^{* *}$ & $82.6 \pm 1.59$ & $85.46 \pm 1.148$ & $73.8 \pm 2.46^{* *}$ \\
\hline Monocytes (\%) & $0-20$ & $13.52 \pm 2.14$ & $10.1 \pm 0.33$ & $10.86 \pm 0.98$ & $9.05 \pm 0.74$ & $11.82 \pm 0.99$ \\
\hline Granulocytes (\%) & $0-27$ & $10.15 \pm 1.58$ & $7.76 \pm 0.83$ & $10.32 \pm 1.42$ & $5.5 \pm 0.55$ & $13.7 \pm 1.69^{*}$ \\
\hline $\operatorname{RBC}\left(10^{6} / \mu \mathrm{L}\right)$ & $5-10$ & $3.65 \pm 0.83$ & $7.41 \pm 0.18^{* *}$ & $4.97 \pm 0.85$ & $4.99 \pm 0.99$ & $6.24 \pm 0.28$ \\
\hline Hematocrit (\%) & $32-53$ & $25.56 \pm 2.99$ & $41.72 \pm 1.09^{* *}$ & $31.93 \pm 3.02^{* *}$ & $31.60 \pm 1.92^{* *}$ & $33.48 \pm 1.30^{*}$ \\
\hline Hemoglobin (g/dL) & $12-18$ & $10.48 \pm 0.57$ & $14.6 \pm 0.54^{*}$ & $13.32 \pm 0.09$ & $9.56 \pm 1.70^{* *}$ & $11.40 \pm 0.44$ \\
\hline MCV (fL) & $52-60$ & $67.80 \pm 5.94$ & $56.80 \pm 0.58$ & $70.20 \pm 7.27$ & $54.2 \pm 0.66$ & $68.20 \pm 11.84$ \\
\hline $\mathrm{MCH}(\mathrm{pg})$ & $17-29$ & $36.38 \pm 8.40$ & $19.62 \pm 0.38$ & $32.80 \pm 7.35$ & $20.20 \pm 1.03$ & $39.92 \pm 16.96$ \\
\hline MCHC (g/dL) & $32-45$ & $50.45 \pm 7.21$ & $34.90 \pm 0.58$ & $44.00 \pm 4.94$ & $37.20 \pm 1.60$ & $48.68 \pm 11.32$ \\
\hline Platelets $\left(10^{3} / \mu \mathrm{L}\right)$ & $200-1100$ & $343.00 \pm 42.97$ & $338.8 \pm 26.36$ & $485.00 \pm 53.95$ & $241.20 \pm 45.33$ & $483.00 \pm 17.68$ \\
\hline
\end{tabular}

Sham (sham operated) and OVX (ovariectomized) animals received the vehicle (distilled water); E2V = OVX animals treated with $1 \mathrm{mg} / \mathrm{kg}$ of $17 \beta$-estradiol valerate; Lannea acida $=$ OVX animals treated with ethanol extract of Lannea acida at doses of 50 and $200 \mathrm{mg} / \mathrm{kg}$ BW. Data are expressed as mean \pm SEM $(n=$ 5); ${ }^{*} p<0.05$ and ${ }^{* *} p<0.01$ as compared to the OVX group.

acida, a suitable biological screening described by Soto et al. [34] and reported in our previous study [24] has been used. The basic principle of this assay is to compare the MCF-7 cells yield following treatment with tested substances with those obtained after estradiol treatment. In this study, the $L$. acida ethanol extract induced a significant increase of MCF-7 cells proliferation at concentrations of 10, 100, and $200 \mu \mathrm{g} / \mathrm{mL}$ as compared to DMSO control. The MCF7 cells proliferation is known as a hallmark of estrogenicity [34], suggesting that $L$. acida have phytoconstituents that mimic estrogenic effects. Indeed, Resende et al. [26] reported that a relative proliferative effect (RPE) $\geq 80 \%$ corresponds to a possible agonistic activity to ER $\alpha$. L. acida induced a RPE $>80 \%$ at the concentration of 100 and $200 \mu \mathrm{g} / \mathrm{mL}$. Consequently, flavonols detected in L. acida ethanol extract might bind ERs and induced cell proliferation. However, this effect could also be an ER-independent effect, due to the fact that MCF-7 cells express ERs, aromatase, and 5 $\alpha$-reductase enzymes, which permit it to elicit estrogenic response involving both genomic and nongenomic pathways [25]. Although an ER binding assay was not assessed in this study, we can hypothesize that flavonoids reported in L. acida could be responsible for the MCF-7 cells proliferation and are potential phytoestrogens. In fact, 4 flavonoids, named as $6,7-\left(2^{\prime \prime}, 2^{\prime \prime}\right.$-dimethyl chromeno)-8- $\gamma, \gamma$-dimethyl allyl flavanone, $3^{\prime}, 4^{\prime}$-dihydroxy-7,8 (2", $2^{\prime \prime}$ - dimethyl chromeno)-6$\gamma, \gamma$-dimethyl allyl flavonol, 7-methyltectorigenin, and irisolidone, have been isolated from barks of the acetone extract of Lannea acida [18]. Irisolidone and tectorigenin (an analogue of 7-methyltectorigenin resulting from the hydrolyzing by intestinal bacteria) have been reported to exhibit estrogenic effects in E-screen assay, as they have induced MCF-7 cells proliferation at concentrations of $0.1,1$, and $10 \mu \mathrm{M}$ [35]. Therefore they could at least partly account for the proliferative activity of $L$. acida on MCF-7 cells observed in this study. Moreover, the concomitant administration of $L$. acida extract with estradiol leads to the decrease of the MCF-7 cells proliferation, suggesting that some of the phytoconstituents of $L$. acida entered in competition with E2V for ERs. The phytoestrogens are well known to bind ERs with $\sim 1000$ times lower affinity than estradiol [36].

Numerous studies showed that estrogen deficiency is accompanied with a marked atrophy of estrogen target organs such as uterus, vagina, and mammary glands [23, 24, 37, 38]. The same observation was done in this study; ovariectomy significantly reduced vaginal epithelium to one cell layer: the stratum germinativum. The uterine wet weight as well as uterine and vaginal epithelial heights decreased dramatically after ovariectomy. As expected, estradiol induced a significant increase in the uterine wet weight and in uterine and vaginal epithelial heights after a 12-week treatment. The uterotrophic effects of estrogen have been attributed to water imbibition or endometrial cells proliferation $[39,40]$. These effects have been reported to be mediated via ER $\alpha$ as demonstrated by the lack of uterine stimulation and mitotic growth responses in $\alpha$ ERKO mice [41]. Lannea acida ethanol extract induced an estrogen-like effect, evidenced by a significant increase in the uterine wet weight and uterine and vaginal epithelial heights at all tested doses (except with the dose of $300 \mathrm{mg} / \mathrm{kg}$ in some parameters) in the 3-day uterotrophic test. These results are in line with the in vitro results obtained in this study and strengthen our hypothesis that the flavonoids detected in L. acida could bind ERs and trigger the genomic mechanism that produces estrogen-like effects. Interestingly, the 12-week treatment of ovariectomized rats with $L$. acida extract did not exhibit estrogenic effect, a part of a slight increase of the uterine epithelial height observed with the dose of $50 \mathrm{mg} / \mathrm{kg}$, indicating that the estrogen-like effects of L. acida extract are time-dependent. These types of effects are specific to phytoestrogens. Indeed, flavonoids are well known phytoestrogens with mixed effects [23, 24, 38, 42].

The postmenopausal-rat model of osteoporosis has been used for decade to characterize natural substances. It shares many characteristics of postmenopausal women bone loss 


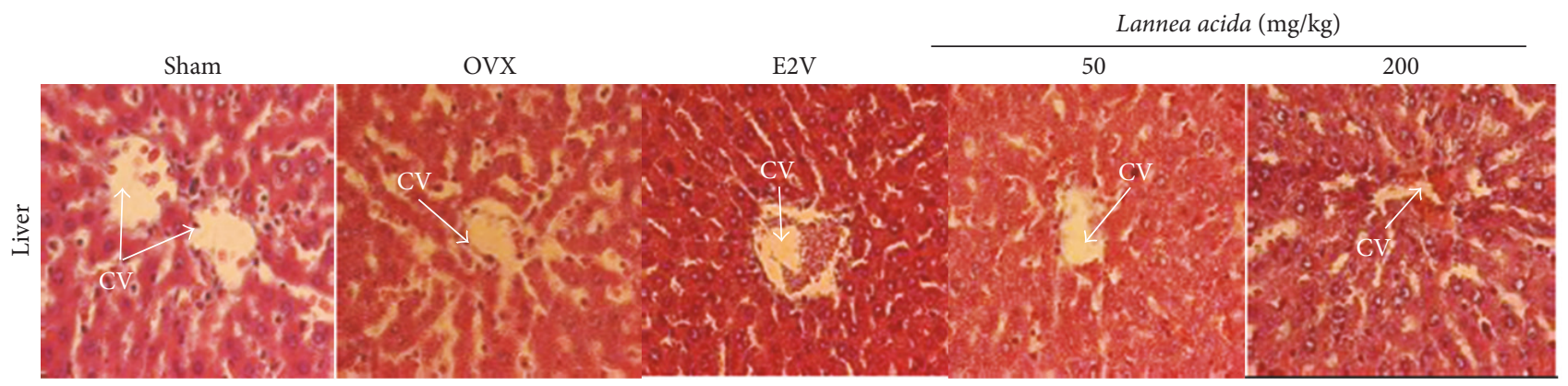

(a)

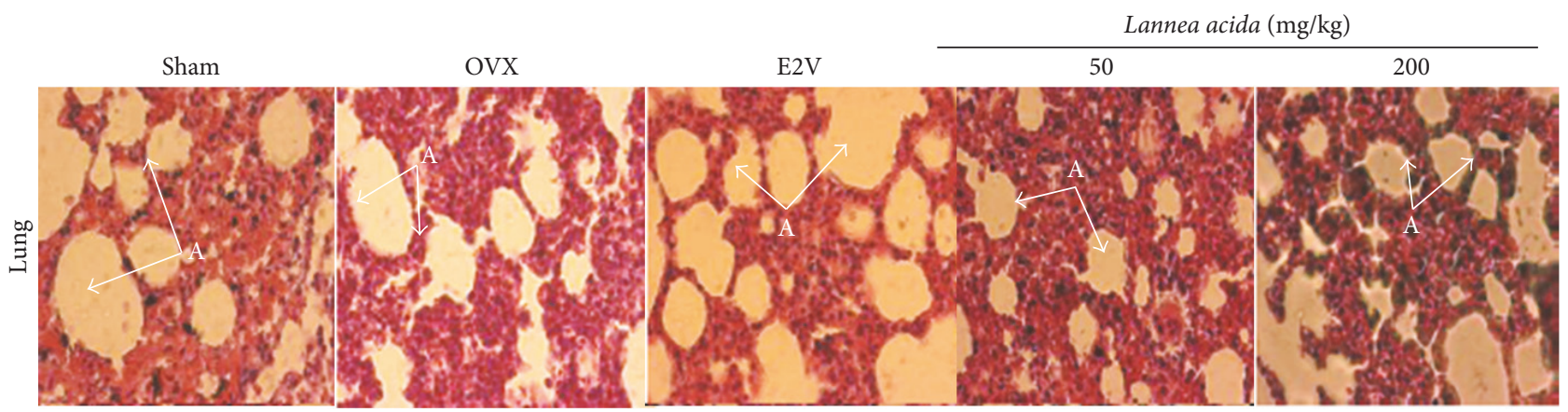

(b)

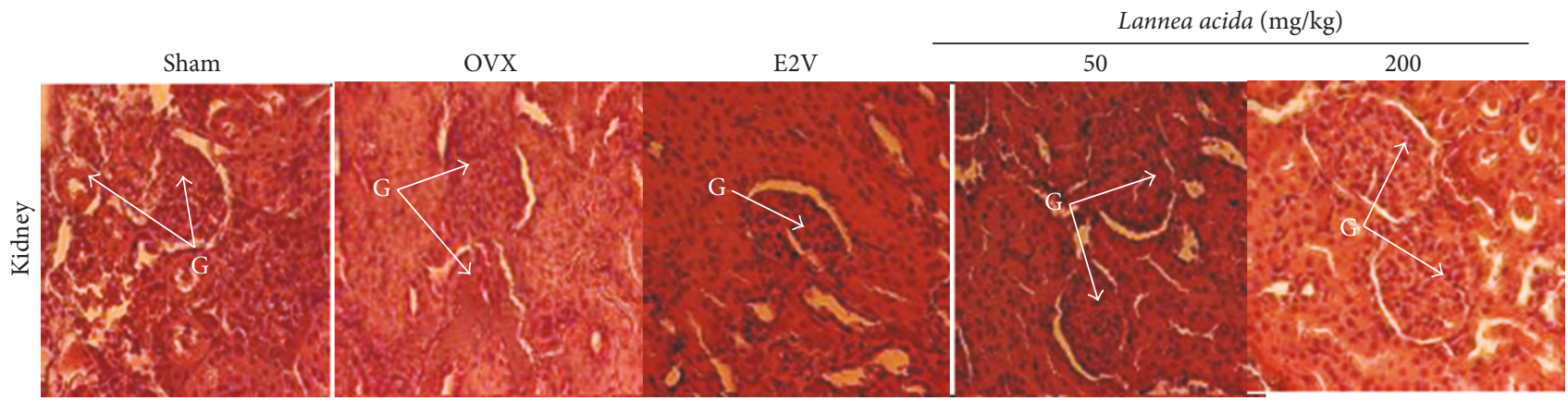

(c)

FIGURE 7: Effects of 11 weeks of treatment with ethanol extract of Lannea acida (LA) or E2V on liver (a), lung (b), and kidney (c) of sham operated or ovariectomized rats. Sham (sham operated) and OVX (ovariectomized) animals received the vehicle (distilled water). E2V $=$ OVX animals treated with $1 \mathrm{mg} / \mathrm{kg}$ of $17 \beta$-estradiol valerate; Lannea acida $=\mathrm{OVX}$ animals treated with ethanol extract of Lannea acida at doses of 50 and $200 \mathrm{mg} / \mathrm{kg} \mathrm{BW}$. Data are expressed as mean \pm SEM $(n=5) . \mathrm{CV}=$ central vein, $\mathrm{A}=$ alveoli; $\mathrm{G}=$ glomeruli.

and therefore it is a suitable model for postmenopausal osteoporosis [43-45]. Following the 12 weeks of administration period, the body weight of ovariectomized rats significantly increased as compared to other groups. This result corroborates previous observations $[45,46]$ and could be explained by an increase in adipose deposition. E2V $(1 \mathrm{mg} / \mathrm{kg})$ and $L$. acida extract at the optimal dose of $200 \mathrm{mg} / \mathrm{kg}$ prevented this body weight gain, probably by mechanisms involving ERs [47]. In fact, estrogen is known to reverse ovariectomy-induced body weight gain. Furthermore, ovariectomy induced a significant decrease of tibia and femur (weight and dried) weights as well as tibia and femur densities. Moreover, a significant decrease in inorganic phosphate level in tibia and a significant increase of serum alkaline phosphatase activity were noted. All these events suggest that ovariectomy enhanced the rate of bone turnover and the experimental osteoporosis was set up in rats. Indeed, the alkaline phosphatase activity is a biomarker of osteoblastic activity associated with bone formation [48]. It is found to increase in osteoporosis and other bone metabolic disorders [41]. Treatment with E2V and L. acida extract at the dose of $200 \mathrm{mg} / \mathrm{kg}$ increased bone (tibia and femur) wet and dried weights as well as bone densities. In addition, these treatments decreased the serum alkaline phosphatase activity and increase the bone inorganic phosphorus content. The aforesaid results suggest that $L$. acida extract reduced bone turnover. The potential preventive effects of estrogen and estrogen-like substances on bone loss have been attributed 

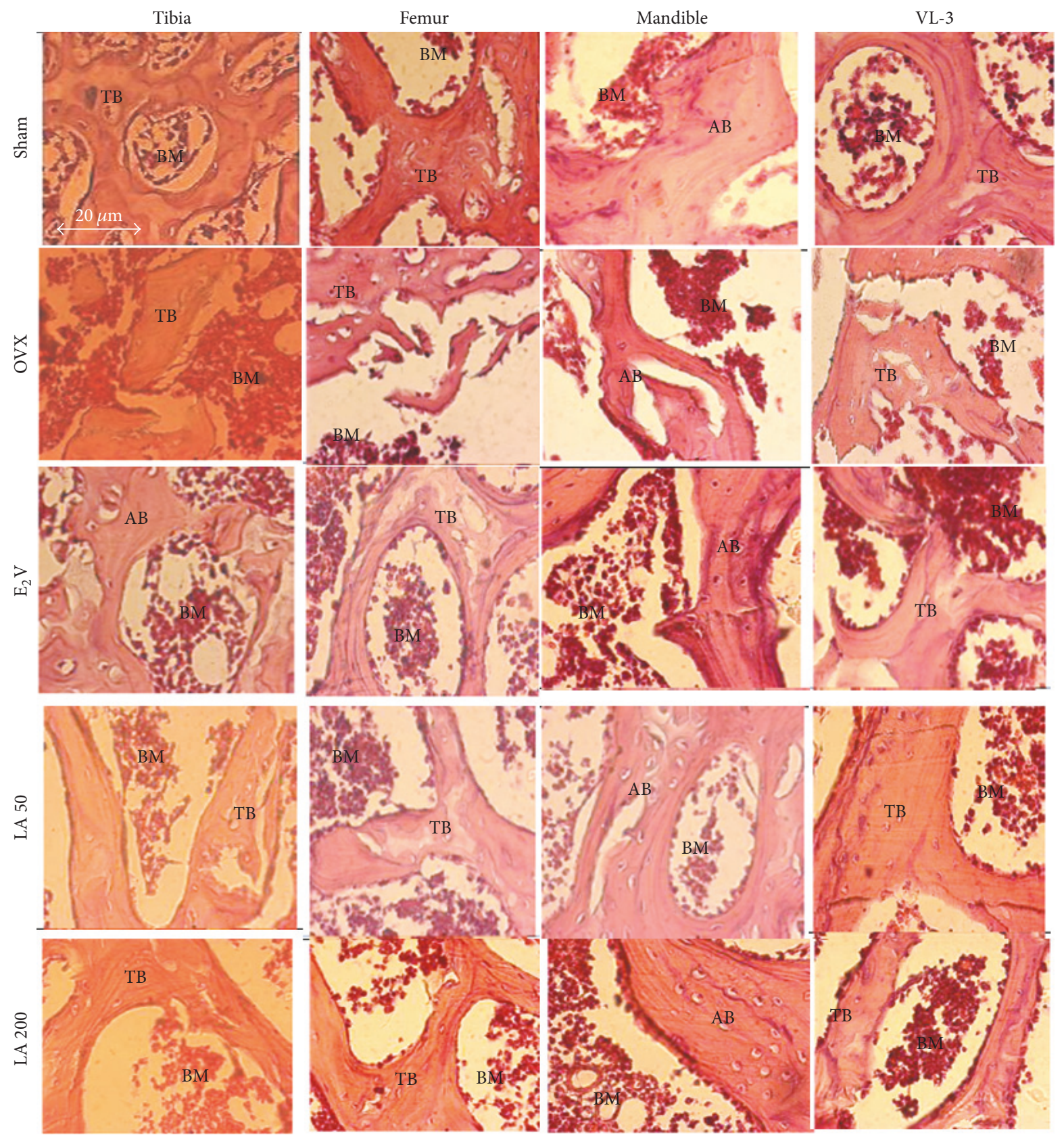

Figure 8: Protective effects of L. acida ethanol extract on histomorphologic (100x magnification) of tibia, femur, VL-3, and mandible. Sham (sham operated) and OVX (ovariectomized) animals received the vehicle (distilled water). E2V = OVX animals treated with $1 \mathrm{mg} / \mathrm{kg}$ of estradiol valerate; Lannea acida $=$ OVX animals treated with ethanol extract of Lannea acida at doses of 50 and $200 \mathrm{mg} / \mathrm{kg}$ BW. Data are expressed as mean \pm SEM $(n=5)$. TB $=$ trabecular bone; $\mathrm{AB}=$ alveolar bone; and $\mathrm{BM}=$ marrow bone.

to their ability to bind ERs on the osteoclast cells and to provoke release of chemical mediators and reduction of the osteoclastic activity [49].

Bone histomorphometry is a technique often used to provide information about bone weight gain or loss in untreated and treated diseases $[28,45,46,50]$. These studies have showed that ovariectomy resulted in increased bone turnover with resorption exceeding formation. This imbalance is known to lead to progressive loss in bone mass and eventually osteoporosis [51]. In accordance with this, our results showed that ovariectomy induced microarchitectural alterations of all the studied bones (VL-3, mandible, femur, and tibia). However, treatments with E2V and Lannea acida extract improved the bone tissue microarchitecture, restoring both cortical and compact bone structure. The same results were observed by Njamen et al. [52] and Zingue et al. [45]. The flavonoids/isoflavonoids of Lannea acida could account for this beneficial effect on bone since phytoestrogens have been 
reported to play an important role in the bone formation through the activation of the ER $\beta$ localized on osteoblast cells [53].

\section{Conclusion}

The ethanol extract of Lannea acida possesses in vitro and in vivo estrogenic effects, materialized by the proliferation of MCF-7 cells and the increase in uterine wet weight and uterine and vaginal epithelial heights. Results also suggest that long-term (3 months) treatment with L. acida extract could prevent estrogen decline-related bone mass loss, microarchitecture alterations, and demineralization. The dose of $200 \mathrm{mg} / \mathrm{kg}$ BW/day was the optimal dose. Taken altogether, this finding provides the evidence that L. acida is a potential alternative for the prevention of postmenopausal osteoporosis which occurs as a consequence of estrogen decline at menopause. In-depth phytochemical investigations are needed to isolate the active principles of $L$. acida and understand the precise mechanism by which it induced estrogenic effect.

\section{Abbreviations}

E2V: Estradiol valerate

ER: Estrogen receptor

$\mathrm{ER} \alpha: \quad$ Estrogen receptor alpha

$\mathrm{ER} \beta$ : Estrogen receptor beta

EtOH: Ethanol

FBS: Fetal bovine serum

HEPES: 4-(2-Hydroxyethyl)-1-piperazine ethane sulfonic acid

CNH: Cameroon National Herbarium

RPMI: Roswell Park Memorial Institute

SERM: Selective estrogen receptor modulators

SEM: Standard error of mean

SRB: Sulforhodamine-B

OVX: Bilaterally ovariectomized rats.

\section{Conflicts of Interest}

The authors declare that there are no conflicts of interest regarding the publication of this paper.

\section{Acknowledgments}

The authors are really grateful to the German Academic Exchange Service (DAAD) and the Alexander von Humboldt Foundation for support. The authors would also kindly thank Professor Tânia Beatriz Creczynski-Pasa (Federal University of Santa Catarina) for the collaboration.

\section{References}

[1] M.-A. Arevalo, I. Azcoitia, and L. M. Garcia-Segura, "The neuroprotective actions of oestradiol and oestrogen receptors," Nature Reviews Neuroscience, vol. 16, no. 1, pp. 17-29, 2015.

[2] P. Pothiwala, E. M. Evans, and K. M. Chapman-Novakofski, "Ethnic variation in risk for osteoporosis among women: A review of biological and behavioral factors," Journal of Women's Health, vol. 15, no. 6, pp. 709-719, 2006.

[3] S. H. Tella and J. C. Gallagher, "Prevention and treatment of postmenopausal osteoporosis," The Journal of Steroid Biochemistry and Molecular Biology, vol. 142, pp. 155-170, 2014.

[4] S. M. Hazavehei, M. H. Taghdisi, and M. Saidi, "Application of the Health Belief Model for osteoporosis prevention among middle school girl students, Garmsar, Iran.” Education for Health (Abingdon), vol. 20, no. 1, p. 23, 2007.

[5] P. Pisani, M. D. Renna, F. Conversano et al., "Major osteoporotic fragility fractures: Risk factor updates and societal impact," World Journal of Orthopedics, vol. 7, no. 3, pp. 171-181, 2016.

[6] International Osteoporosis Foundation, "The Middle East \& Africa Regional Audit: Epidemiology, costs \& burden of osteoporosis in 2011," 2011, https://www.iofbonehealth.org/middleeast-africa-audit.

[7] C. Cooper, G. Campion, and L. J. Melton III, "Hip fractures in the elderly: a world-wide projection," Osteoporosis International, vol. 2, no. 6, pp. 285-289, 1992.

[8] R. M. D. Zebaze and E. Seeman, "Epidemiology of hip and wrist fractures in Cameroon, Africa," Osteoporosis International, vol. 14, no. 4, pp. 301-305, 2003.

[9] G. A. Greendale, B. A. Reboussin, P. Hogan et al., "Symptom relief and side effects of postmenopausal hormones: Results from the postmenopausal estrogen/progestin interventions trial," Obstetrics \& Gynecology, vol. 92, no. 6, pp. 982-988, 1998.

[10] K. C. Nichols, L. Schenkel, and H. Benson, "17 $\beta$-Estradiol For Postmenopausal Estrogen Replacement Therapy," Obstetrical \& Gynecological Survey, vol. 39, no. 4, pp. 230-245, 1984.

[11] S. Pozzi, R. Marcheselli, S. Sacchi et al., "Bisphosphonateassociated osteonecrosis of the jaw: A review of 35 cases and an evaluation of its frequency in multiple myeloma patients," Leukemia \& Lymphoma, vol. 48, no. 1, pp. 56-64, 2007.

[12] J. E. Rossouw, G. L. Anderson, R. L. Prentice et al., "Risks and benefits of estrogen plus progestin in healthy postmenopausal women: Principal results from the women's health initiative randomized controlled trial," Journal of the American Medical Association, vol. 288, no. 3, pp. 321-333, 2002.

[13] Million Women Study Collaborators, "Breast cancer and hormone-replacement therapy in the Million Women Study," The Lancet, vol. 362, no. 9382, pp. 419-427, 2003.

[14] L. S. Gill, Ethno-Medicine Uses of Plant in Nigeria, Bieger N: Beekeepingand Community Forest Management, 276, University of Benin Press, Nigeria, 1992.

[15] H. Ellenberg, H. E. Weber, R. Dü 1l, V. Wirth, W. Werner, and D. Paulissen, Pirrang: Ecological Investigationin ForestIsland in the Gambia, vol. 2, pp: 23-456, Gambian Press, 1998.

[16] M. Arbonnier, "Arbres, arbustes et lianes des zones sèches d'Afrique de l'Ouest," pp. 396-416, 2009, Editions Quæ RD 10; F- 78026 Versailles Cedex, France; ISBN Quæ 978-2-7592-03130; Muséum National d'histoire Naturelle (MNHN); Service des publications scientifiques, 57 Rue Cuvier, F- 75005, Paris, France; ISBN MNHN 978-2-85653-626-1.

[17] M. K. Ahmed, M. A. Mabrouk, J. A. Anuka et al., "Studies of the effect of methanolic stem bark extract of Lannea acida on fertility and testosterone in male wistar rats," Journal of Medical Sciences, vol. 7, no. 6-7, 2010.

[18] H. M. H. Muhaisen, "Chemical constituents from the bark of Lannea acida rich (anacardiaceae)," Scholars Research Library, vol. 5, no. 5, pp. 88-96, 2013. 
[19] A. Odebiyi and A. E. Sofowora, "Phytochemical screening of Nigerian medical plants part II," Lloydia, vol. 41, pp. 234-246, 1978.

[20] V. L. Singleton and J. A. Rossi, "Colorimetry of total phenolics with phosphomolybdic-phosphotungstic acid reagents," American Journal of Enology and Viticulture, vol. 37, pp. 144-158, 1965.

[21] J. Zhishen, T. Mengcheng, and W. Jianming, "The determination of flavonoid contents in mulberry and their scavenging effects on superoxide radicals," Food Chemistry, vol. 64, no. 4, pp. 555$559,1999$.

[22] S. Fazel, M. Hamidreza, G. Rouhollah, and V. Mohammadreza, "Spectrophotometric determination of total alkaloids in some Iranian medicinal plants," Thai Journal of Pharmaceutical Sciences, vol. 32, pp. 17-20, 2008.

[23] S. Zingue, T. Michel, C. B. Magne Nde et al., "Estrogen-like and tissue-selective effects of 7-methoxycoumarin from Ficus umbellata (Moraceae): an in vitro and in vivo study," $B M C$ Complementary and Alternative Medicine, vol. 17, no. 1, 383 pages, 2017.

[24] S. Zingue, J. Tchoumtchoua, D. M. Ntsa et al., "Estrogenic and cytotoxic potentials of compounds isolated from Millettia macrophylla Benth (Fabaceae): Towards a better understanding of its underlying mechanisms," BMC Complementary and Alternative Medicine, vol. 16, pp. 421-437, 2016.

[25] T. Schilirò, I. Gorrasi, A. Longo, S. Coluccia, and G. Gilli, "Endocrine disrupting activity in fruits and vegetables evaluated with the E-screen assay in relation to pesticide residues," The Journal of Steroid Biochemistry and Molecular Biology, vol. 127, no. 1-2, pp. 139-146, 2011.

[26] F. A. Resende, A. P. S. de Oliveira, M. S. de Camargo, W. Vilegas, and E. A. Varanda, "Evaluation of Estrogenic Potential of Flavonoids Using a Recombinant Yeast Strain and MCF7/BUS Cell Proliferation Assay," PLoS ONE, vol. 8, no. 10, Article ID e74881, 2013.

[27] OECD, "Third meeting of the validation management group for the screening and testing of endocrine disrupters (mammalian effects)," 2007, Joint meeting of the chemicals committee and the working party on chemical, pesticides and biotechnology, http://www.oecd.org.

[28] L. M. F. Lucinda, B. J. Vieira, T. T. Oliveira et al., "Evidences of osteoporosis improvement in Wistar rats treated with Ginkgo biloba extract: A histomorphometric study of mandible and femur," Fitoterapia, vol. 81, no. 8, pp. 982-987, 2010.

[29] Y.-B. Lee, H. J. Lee, K. S. Kim et al., "Evaluation of the preventive effect of isoflavone extract on bone loss in ovariectomized rats," Bioscience, Biotechnology, and Biochemistry, vol. 68, no. 5, pp. 1040-1045, 2004.

[30] C. Cannet, "Artéfacts: les difficultés de la technique histologique de la circulation à la coupe," in Rev Fr Histotechnol, vol. 19, pp. 71-84, 2006.

[31] J. F. Fortier and R. Hould, Histotechnologie: théorie et procédés, CCDMD edition edition, 2003.

[32] A. G. Gonal, G. S. Bardwill, and M. M. David, "Determination of serum proteins by the means of biuret reactions," The Journal of Biological Chemistry, vol. 177, pp. 751-766, 1949.

[33] R. Montgomery, "Determination of glycogen," Archives of Biochemistry and Biophysics, vol. 67, no. 2, pp. 378-386, 1957.

[34] A. M. Soto, T. M. Lin, H. Justicia, R. M. Silvia, and C. Sonnenschein, "An "in culture" bioassay to assess the estrogenicity of xenobiotics," in Chemically induced alterations in sexual development: The wildlife/human connection Princeton, T. Colborn and C. Clement, Eds., pp. 295-309, NJ: Princeton Scientific Publishing, 1992.

[35] J.-E. Shin, E.-A. Bae, Y. C. Lee, J.-Y. Ma, and D.-H. Kim, "Estrogenic effect of main components kakkalide and tectoridin of puerariae flos and their metabolites," Biological \& Pharmaceutical Bulletin, vol. 29, no. 6, pp. 1202-1206, 2006.

[36] P. J. Magee and I. R. Rowland, "Phyto-oestrogens, their mechanism of action: Current evidence for a role in breast and prostate cancer," British Journal of Nutrition, vol. 91, no. 4, pp. 513-531, 2004.

[37] F. R. Westwood, “The Female Rat Reproductive Cycle: A Practical Histological Guide to Staging," Toxicologic Pathology, vol. 36, no. 3, pp. 375-384, 2008.

[38] M. A. Mvondo, D. Njamen, S. T. Fomum, J. Wandji, and G. Vollmer, "A postmenopause-like model of ovariectomized Wistar rats to identify active principles of Erythrina lysistemon (Fabaceae)," Fitoterapia, vol. 82, no. 7, pp. 939-949, 2011.

[39] D. F. Archer, "Neoplasia of the female reproductive tract: Effects of hormone therapy," Endocrine Journal, vol. 24, no. 3, pp. 259263, 2004.

[40] D. Seidlová-Wuttke, T. Becker, V. Christoffel, H. Jarry, and W. Wuttke, "Silymarin is a selective estrogen receptor $\beta(\operatorname{ER} \beta)$ agonist and has estrogenic effects in the metaphysis of the femur but no or antiestrogenic effects in the uterus of ovariectomized (ovx) rats," The Journal of Steroid Biochemistry and Molecular Biology, vol. 86, no. 2, pp. 179-188, 2003.

[41] S. C. Hewitt, B. J. Deroo, K. Hansen et al., "Estrogen ReceptorDependent Genomic Responses in the Uterus Mirror the Biphasic Physiological Response to Estrogen," Molecular Endocrinology, vol. 17, no. 10, pp. 2070-2083, 2003.

[42] K. D. R. Setchell, "Soy Isoflavones-Benefits and Risks from Nature's Selective Estrogen Receptor Modulators (SERMs)," Journal of the American College of Nutrition, vol. 20, pp. 354$362,2001$.

[43] D. N. Kalu, "The ovariectomized rat model of postmenopausal bone loss," Bone and Mineral, vol. 15, no. 3, pp. 175-191, 1991.

[44] A. N. Shuid, L. L. Ping, N. Muhammad, N. Mohamed, and I. N. Soelaiman, "The effects of Labisia pumila var. alata on bone markers and bone calcium in a rat model of post-menopausal osteoporosis," Journal of Ethnopharmacology, vol. 133, no. 2, pp. 538-542, 2011.

[45] S. Zingue, D. Njamen, M. A. Mvondo, and C. B. Magne Nde, "Preventive effects of the methanol soluble fraction of Millettia macrophylla Benth (Fabaceae) on an osteoporosis-like model of ovariectomized Wistar rats," Journal of Complementary and Integrative Medicine, vol. 11, no. 2, pp. 83-92, 2014.

[46] S. B. Ateba, D. Njamen, S. Medjakovic et al., "Eriosema laurentii de Wild (Leguminosae) methanol extract has estrogenic properties and prevents menopausal symptoms in ovariectomized Wistar rats," Journal of Ethnopharmacology, vol. 150, no. 1, pp. 298-307, 2013.

[47] A. Naaz, M. Zakroczymski, P. Heine et al., "Effect of ovariectomy on adipose tissue of mice in the absence of estrogen receptor alpha $(\mathrm{ER} \alpha)$ : A potential role for estrogen receptor beta (ER $\beta$ )," Hormone and Metabolic Research, vol. 34, no. 11-12, pp. 758-763, 2002.

[48] L. J. Robert and C. M. Stavros, The Cellular and Biomechanical Basis of Bone Remodeling, R. Marcus, Ed., pp. 22-23, Osteoporosis. Blackwell. Publications, London, 1994.

[49] V. P. Arcangelo and A. M. Peterson, Pharmacotherapeutics for Advanced Practice: A Practical Approach, PA: Lippincott Williams \& Wilkins, Philadelphia, 2nd edition, 2005. 
[50] J. Compston, "Bone histomorphometry: the renaissance?” Bone Key-Osteovision, vol. 1, no. 5, pp. 9-12, 2004.

[51] M. Bolognese, J. H. Krege, W. H. Utian et al., "Effects of arzoxifene on bone mineral density and endometrium in postmenopausal women with normal or low bone mass," The Journal of Clinical Endocrinology \& Metabolism, vol. 94, no. 7, pp. 22842289, 2009.

[52] D. Njamen, S. Djiogue, S. Zingue, M. A. Mvondo, and B. N. Nkeh-Chungag, "In vivo and in vitro estrogenic activity of extracts from Erythrina poeppigiana (Fabaceae)," Journal of Complementary \& Integrative Medicine, vol. 10, pp. 1-11, 2013.

[53] G. Silvestrini, P. Ballanti, F. R. Patacchioli et al., "Evaluation of apoptosis and the glucocorticoid receptor in the cartilage growth plate and metaphyseal bone cells of rats after high-dose treatment with corticosterone," Bone, vol. 26, no. 1, pp. 33-42, 2000 . 


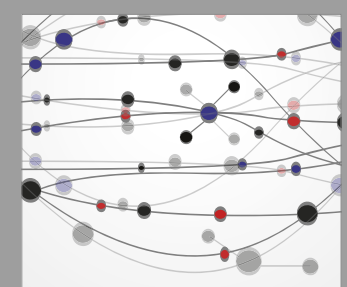

The Scientific World Journal
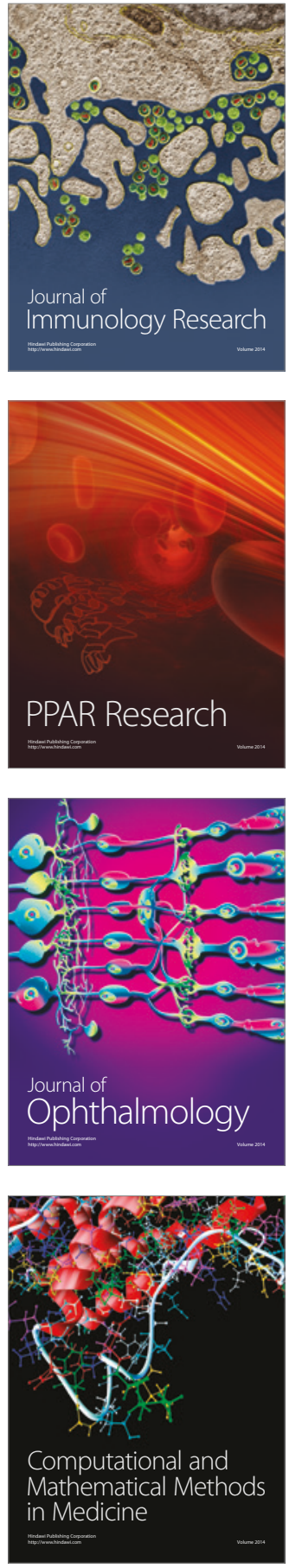

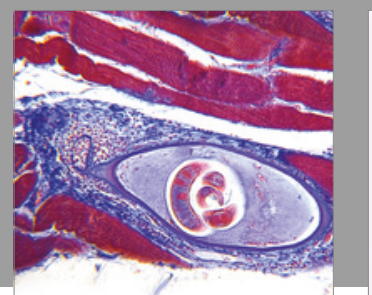

Gastroenterology Research and Practice
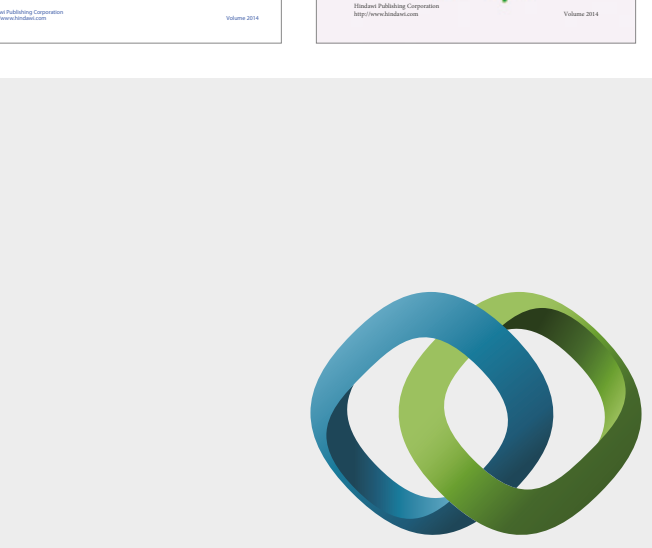

\section{Hindawi}

Submit your manuscripts at

https://www.hindawi.com
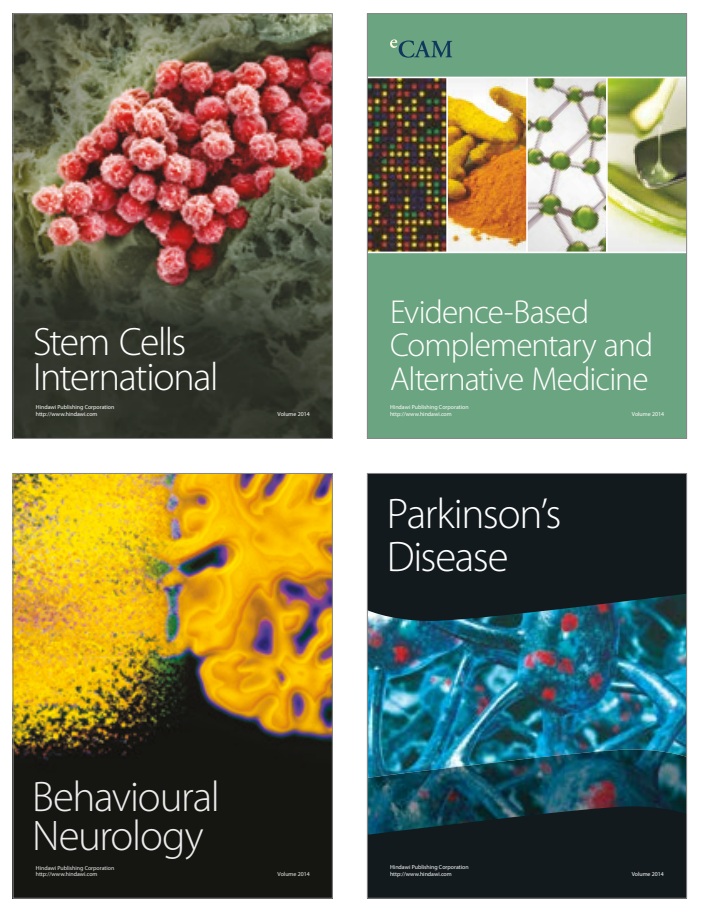
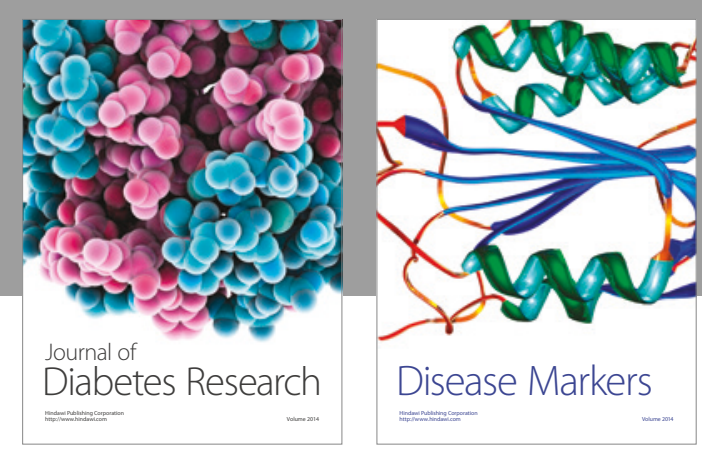

Disease Markers
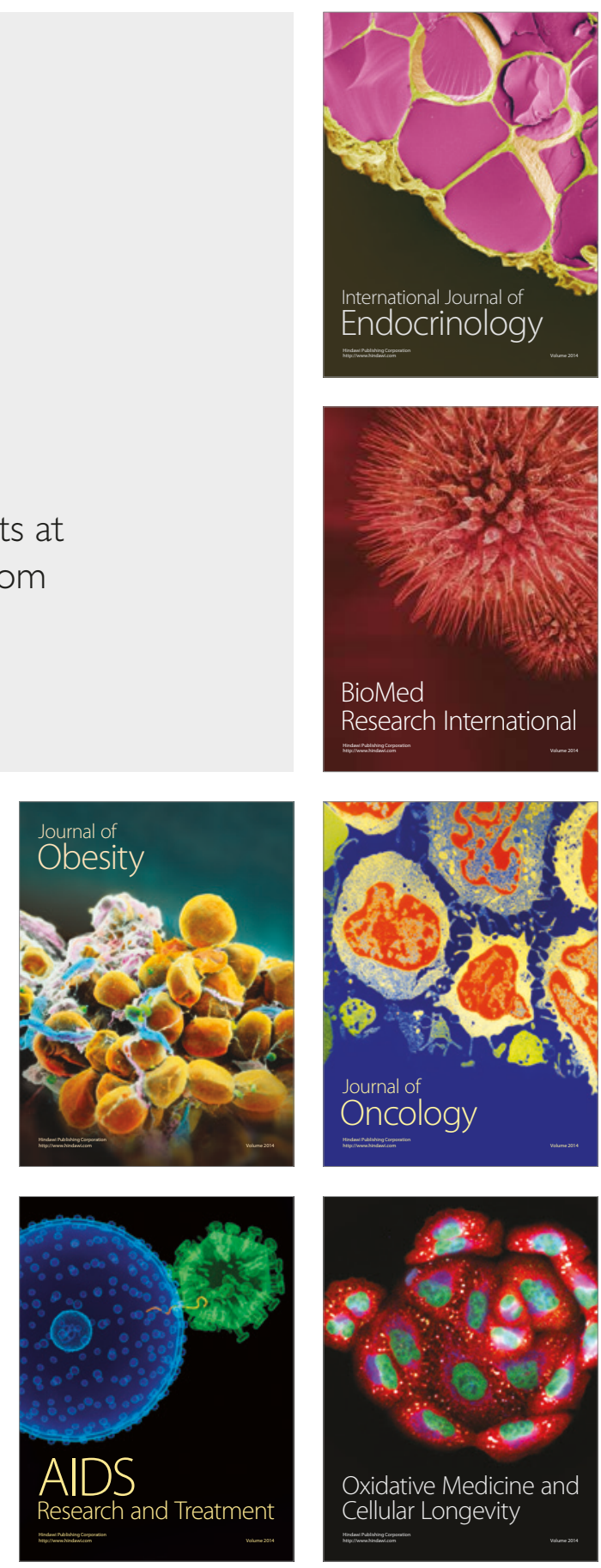